


\title{
Postpartum Infections; Prevalence, Associated Obstetric Factors and the Role of Vitamin D
}

\author{
Daniel Axelsson
}

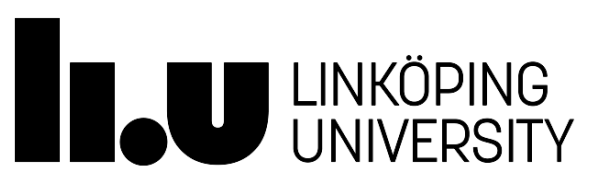

Department of Obstetrics and Gynecology,

Ryhov County Hospital, Jönköping, Sweden

Department of Clinical and Experimental Medicine

Linköping University, Linköping, Sweden 
Postpartum Infections; Prevalence, Associated Obstetric Factors and the Role of Vitamin D

(C) Daniel Axelsson 2019

Cover:

Front: "Life" Daniel Axelsson

Back: "Together" Daniel Axelsson

Printed by LiU-Tryck, Linköping, Sweden, 2019

ISBN 978-91-7685-054-1

ISSN 0345-0082 
You can if you want to 



\section{ABSTRACT}

Background: Postpartum infections are a major cause of maternal mortality and morbidity worldwide. Breast infection, endometritis, urinary tract infection and wound infections are the most common postpartum infections and together they affect almost $20 \%$ of women after childbirth. Some risk factors for postpartum infections, for example cesarean section, have been relatively well studied, but other presumable risk factors are yet to be confirmed.

The proportion of pregnant women who are overweight or obese is increasing in most parts of the world. Increased maternal body mass index (BMI) is associated with maternal and infant morbidity. The association between overweight / obesity and postpartum infections is incompletely understood. Vitamin D deficiency has in epidemiological studies been shown to increase the risk of various infections. Furthermore, vitamin $\mathrm{D}$ is an important factor in the human immune system. Concomitantly, vitamin D supplementation seems protective against some types of infections. Whether vitamin $\mathrm{D}$ deficiency is a risk factor for postpartum infections has not been studied.

Material and Methods: In a population-based observational study using questionnaires, the prevalences of postpartum wound infections, endometritis, urinary tract infections and mastitis in the southeast region of Sweden were estimated (paper I). All women giving birth in the region during one year $(\mathrm{n}=11$ 124) were asked to participate. Papers II and III were cohort studies based on all deliveries in Sweden during eight years (2005-2012). Data sources were the Swedish Medical Birth Register, the Swedish National Patient Register and the Swedish Prescribed Drugs Register. In paper II all term deliveries were included $(\mathrm{n}=795$ 072). Risk factors for postpartum wound infections, endometritis and urinary tract infection were evaluated. Paper III included all deliveries $(\mathrm{n}=841$ 780) and examined the impact of BMI on the risk of postpartum wound infections, endometritis and breast abscess after different modes of delivery. Infections were defined as the presence of applicable ICD-10 codes. The Mantel-Haenszel technique was used to calculate adjusted odds ratios. In paper IV the association between vitamin D deficiency and overall postpartum infectious morbidity was analyzed. Serum samples from the Pregnancy Biobank in Linköping, drawn at the time of delivery, were used to determine concentrations of 25-hydroxyvitamin D in 1397 women. ICD-10 codes were extracted from the women's medical records. The prevalence of vitamin D deficiency was calculated and adjusted odds ratios for postpartum infections were estimated with multivariable logistic regression analysis.

Results: More than one out of ten women in southeast Sweden reported wound infections; endometritis, urinary tract infection or mastitis postpartum and 7.5\% 
reported antibiotic treatment for infection. Cesarean section was the strongest risk factor for wound infection, followed by obstetric anal sphincter injuries and episiotomy. For endometritis, the strongest risk factors were anemia, manual placental removal and emergency cesarean section. Urinary tract infection was associated with anemia, instrumental vaginal delivery and emergency cesarean section. There was a dose-dependent increased risk of postpartum infection with higher BMI. For morbidly obese women the risk of infection was over $50 \%$ higher than for normal weight women. The risk of endometritis after normal vaginal delivery increased the higher the BMI, as did the risk of wound infection after cesarean section, regardless of the type of cesarean section. For breast abscess, there was an inverse association with BMI.

Vitamin D deficiency was present among almost $60 \%$ of pregnant women at the time of delivery. No association between vitamin D deficiency and postpartum infections was found.

Conclusions: Every tenth Swedish woman acquired an infection postpartum and three quarters of them received antibiotics for infection. Anemia was an important risk factor for postpartum infection, and the strongest risk factor for endometritis and urinary tract infection. Strong efforts should be made to reduce blood loss during and after childbirth. This thesis confirmed cesarean section as a major risk factor for postpartum infection, especially wound infection. The risk increased if the woman was overweight or obese, regardless of whether it was a planned or an emergency cesarean section.

Vitamin D deficiency was common among Swedish pregnant women, but it was not found to be associated with postpartum infections. 


\section{LIST OF SCIENTIFIC PAPERS}

I. Prevalence of postpartum infections: a population-based observational study

Daniel Axelsson and Marie Blomberg Acta Obstet Gynecol Scand 2014;93:1065-1068

II. Postpartum infection in relation to maternal characteristics, obstetric interventions and complications

Daniel Axelsson, Jan Brynhildsen and Marie Blomberg J Perinat Med. 2018;46(3);271-278

III. Obesity and the risk of postpartum infections according to mode of delivery

Daniel Axelsson, Jan Brynhildsen and Marie Blomberg In manuscript

IV. Vitamin D deficiency and postpartum infections

Daniel Axelsson, Jan Brynhildsen and Marie Blomberg Submitted

The published papers are reprinted with permission from the publishers. 



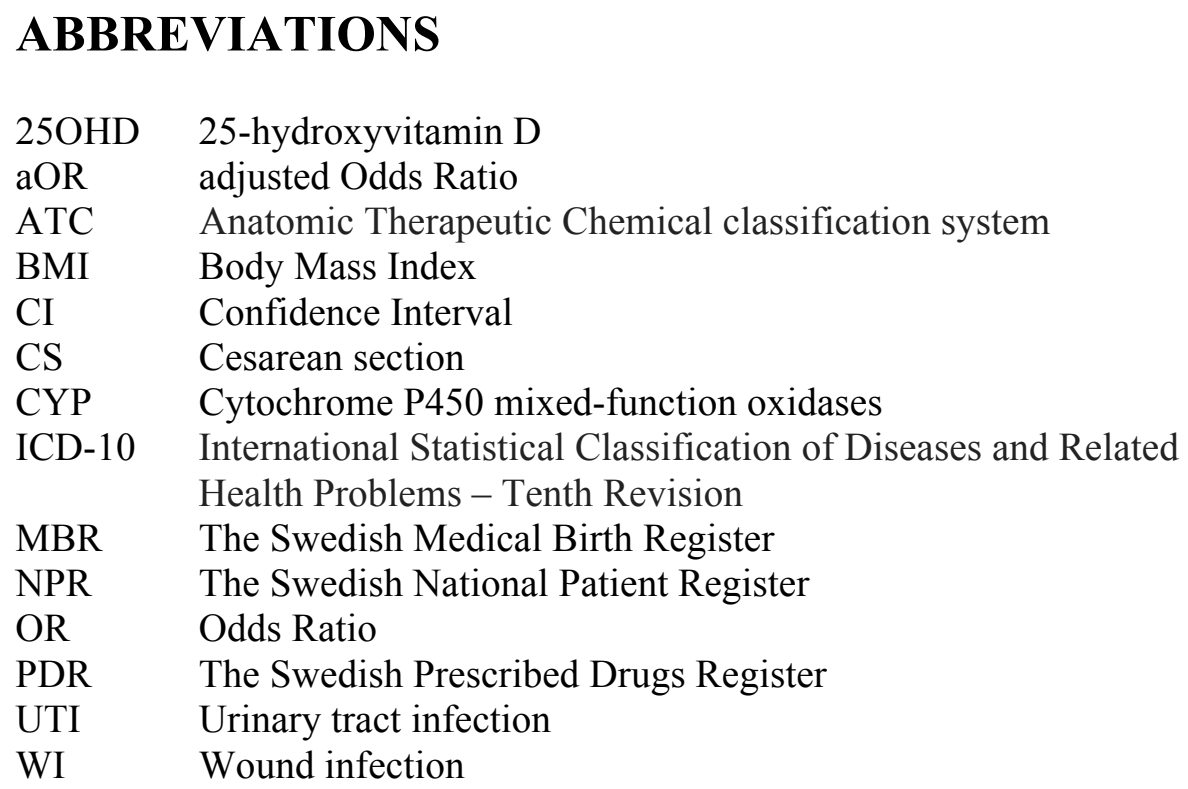





\section{CONTENTS}

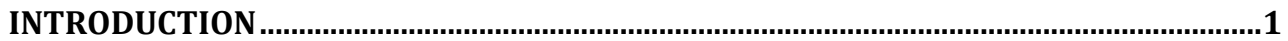

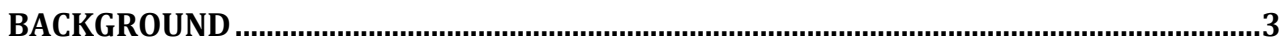

Postpartum infectious morbidity and surveillance ………………………………………... 3

Endometritis ...................................................................................................................... 3

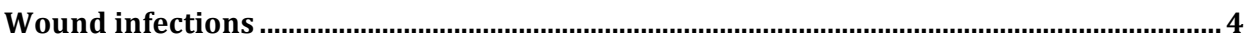

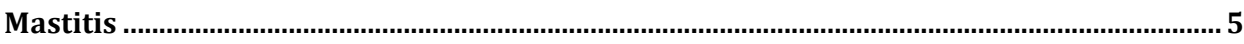

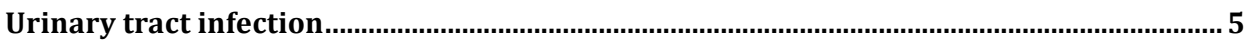

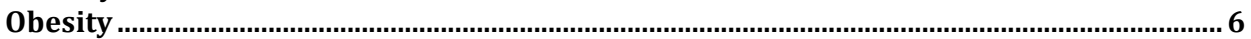

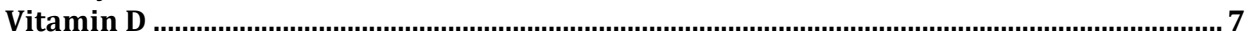

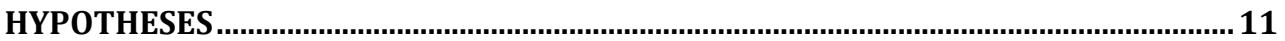

AIMS

MATERIAL AND METHODS .................................................................................13

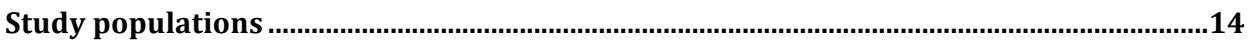

The southeast region of Sweden ………………………………………………………………..17

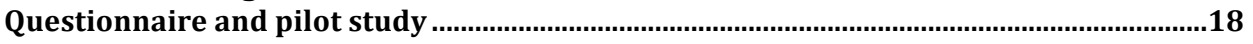

The Swedish Medical Birth Register....…………………………………………………………18

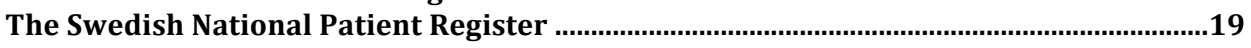

The Swedish Prescribed Drugs Register ...............................................................................20

Register Data extraction and combination .............................................................................21

The Pregnancy Biobank ..............................................................................................................21

Analysis of Vitamin D ..............................................................................................................23

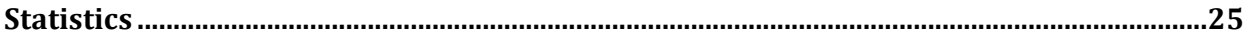

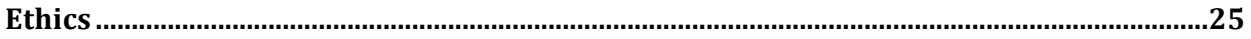

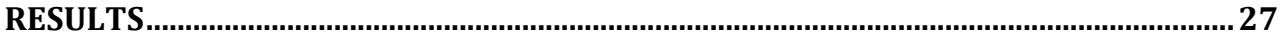

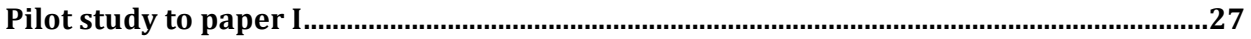

Paper I.............................................................................................................................27

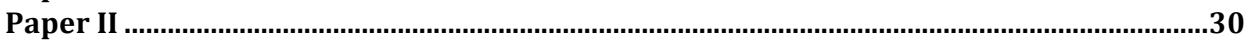

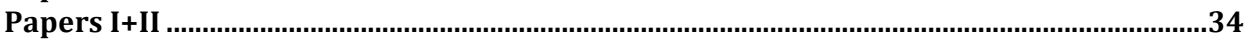

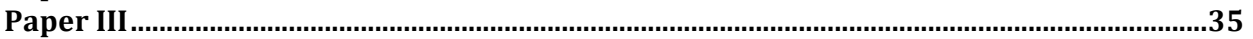

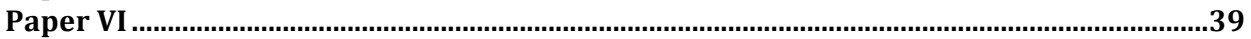

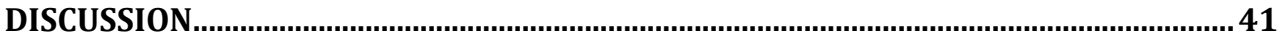

Discussion of the findings ....................................................................................................41

Prevalence of postpartum infections .......................................................................................................... 41

Putative risk factors for postpartum infections ...................................................................................... 41

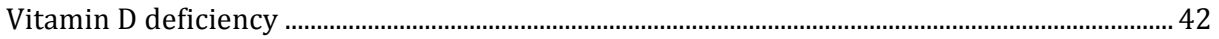

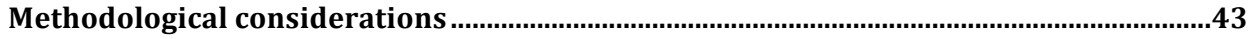

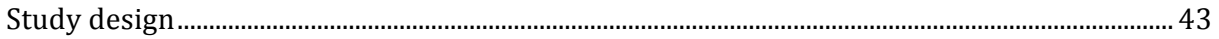

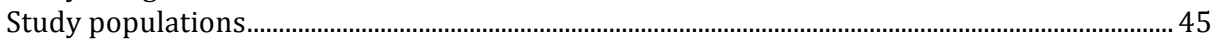

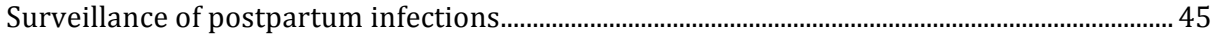

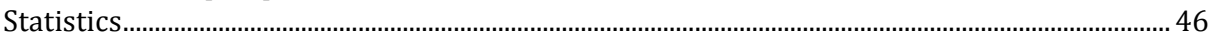

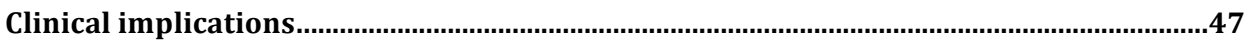

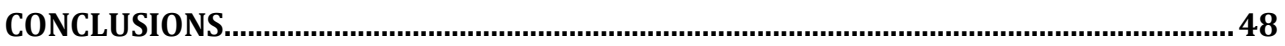

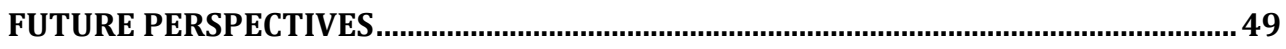

POPULÄRVETENSKAPLIG SAMMANFATTNING ..................................................50

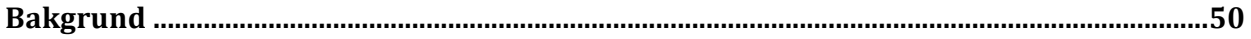

Syfte med avhandlingen 


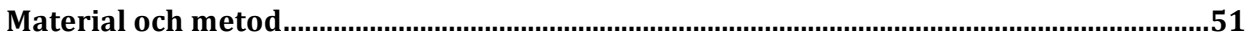

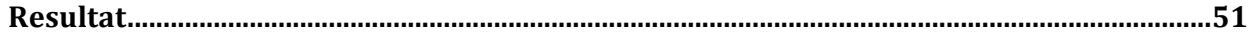

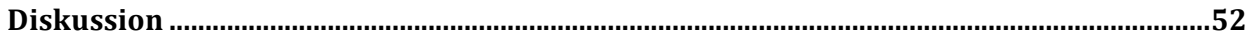

ACKNOWLEDGEMENTS ............................................................................................... 53

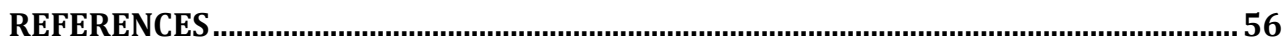

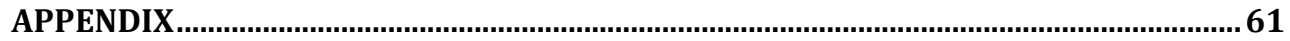




\section{INTRODUCTION}

Childbed fever, or puerperal fever, was the leading cause of maternal mortality in Europe in the 18th and 19th centuries (1). It mainly affected women who gave birth with the assistance of physicians, and was far more common when delivery took place in a hospital than at home. Symptoms of the disease were high fever, abdominal pain, increased heart rate and debility, and often death resulted (2). In epidemic cases of childbed fever the mortality was reported to be as high as 70 to 80 percent (1). Many theories about the cause were put forward. Among these, Alexander Gordon in Aberdeen in the late 18th century proposed a spread between patients caused by doctors and midwives (3). The American doctor Oliver Wendell Holmes argued in 1843 that physicians should wash their hands between deliveries to prevent the spread of the disease (2). Most attention has been given to Ignaz Semmelweis, a Hungarian doctor who worked in a hospital in Vienna during the 1840s. He discovered that the mortality rate in childbed fever in delivery ward 1, which was run by medical students who also worked on autopsies, was five times higher than that in delivery ward 2, where midwife students delivered women. When a Professor, admired by Semmelweis, died while showing symptoms of childbed fever after having cut his finger during an autopsy, Semmelweis came to the conclusion that medical students transferred some contagious matter from the dead bodies to the laboring women. After having implemented the mandatory washing of hands with chlorinated solutions the mortality rate from childbed fever in ward 1 fell from 12 to one percent from one month to the next (4). Later, the discovery of antibiotics in the 20th century dramatically lowered the maternal mortality related to infections in the developed world. Nevertheless, in the 21th century postpartum infections are still a major cause of maternal mortality in the world (5-7). However, the absolute risk of mortality in the puerperium is small in developed countries, but infectious morbidity continues to cause human and economic suffering (5). In order to reduce the prevalence of postpartum infections a good knowledge about their risk factors is required. Some risk factors, for example cesarean section (CS), are relatively well studied (8-10), but several other presumable risk factors are yet to be confirmed.

The proportion of pregnant women who are overweight or obese is increasing in most parts of the world. Increased maternal BMI has been shown to be associated with numerous complications for the pregnant or recently delivered woman, her fetus and later her newborn child (11). An association between overweight / obesity and puerperal infections, predominantly wound infections (WI), has also been previously described $(11,12)$. There is, however, limited knowledge about the effect of increasing BMI on the risk of other postpartum infections and after different modes of delivery. 
Vitamin D has attracted increasing attention regarding its role in the human defense against infections (13). In epidemiological studies, vitamin D deficiency has been shown to increase the risk of various infections (13-15), but its possible association with postpartum infections has not been studied. 


\section{BACKGROUND}

\section{Postpartum infectious morbidity and surveillance}

During the puerperium, women have an increased risk of infection. The most common infections associated with childbirth are endometritis, infections in perineal or cesarean wounds, UTI and mastitis (6). All of these postpartum infections have been reported to predominantly present after discharge from hospital(16-20). The prevalence of infections has therefore been reported to be at various levels, depending on health care systems, the availability of health care, mode of surveillance and different definitions. Postpartum infection is the most common cause of prolonged hospital stay and the second most common cause of readmission after childbirth, regardless of mode of delivery $(18,21)$. Surveillance of the prevalence of specific infection after childbirth in Sweden is difficult, since the obstetric care providers do not routinely follow up regarding infections. Most delivery wards have electronic patient record systems designed exclusively for obstetric care, while other care providers have a different medical record system. Data from obstetric care are reported to the Swedish Medical Birth Register (MBR) (22), whereas other public specialist in- and outpatient caregivers report data to the Swedish National Patient Register (NPR) (23). The primary health care in Sweden does not report to any of these registers. Filled prescriptions of antibiotics are reported to the Swedish Prescribed Drugs Register (PDR) (24), but the register lacks information about the indication for the prescription.

Consequently, to study postpartum infections can be challenging and no studies specifically aimed at describing the prevalence in Sweden have been published.

\section{Endometritis}

In the literature, endometritis is also referred to as endomyometritis, endomyoparametritis or just metritis. These terms are based on the depth of invasion of the infection into the maternal tissue. In clinical praxis, it is usually neither possible nor of great importance to determine the exact magnitude of the uterine infection, since treatment does not differ significantly in these instances. Since there is no way to differentiate between the different types of uterine infection in medical registers, uterine infection after delivery is referred to as endometritis in this thesis. Endometritis has been reported to affect $0.17 \%$ to $30 \%$ of women postpartum, depending on the mode of delivery and method of surveillance $(7-9,18,20,25)$. The only available Swedish prevalence data from the early $1990 \mathrm{~s}$, showed a prevalence of postpartum endometritis of $2.5 \%$ (26). 
A neighboring or overlapping term is "puerperal sepsis". It has been defined by the World Health Organization (WHO) as fever during the first 42 days postpartum, along with one or more of the following signs (6):

- Pelvic pain

- Abnormal vaginal discharge

- Abnormal odor of discharge

- Delay in the involution of the uterus

The International Classification of Diseases (ICD-10) defines puerperal sepsis as a temperature rise above 38 degrees Celsius maintained over 24 hours during the first ten days following childbirth or abortion (6).

Hence, puerperal sepsis is a somewhat non-specific term to which several different infections and other more or less severe complications apply. The diagnosis endometritis is usually based on a combination of fever, uterine tenderness, abnormal discharge (abnormal visually or malodorous) and a significant rise in white blood count and / or C-reactive protein (6).

The microbiological cause of specific cases of endometritis is usually difficult to determine, since cultures taken postpartum tend to be contaminated from this non-sterile environment (6). In the classical childbed fever, endometritis was caused by group A streptococci, causing a dramatic course of infection, often with a fatal outcome (1). This pathogen is rarely seen in obstetric infections nowadays, even if epidemic outbreaks are reported now and then. Most cases of endometritis have a polymicrobial cause where both aerobic gram-positive and gram-negative cocci and rods are found (27). Concomitantly, over two thirds of clinically healthy puerperal women have been found to have at least one pathogen in their uterine cavity $(28,29)$.

\section{Wound infections}

WIs are most common after CS, but vaginal delivery may also be complicated by infection. Vaginal tears, particularly Obstetric Anal Sphincter Injuries (OASIS), and episiotomies can be infected with various pathogens (30).

The wound after CS has been described to be infected in $0.2 \%$ to $16 \%$ of cases compared with $0.3 \%$ of wounds after vaginal delivery $(6,8,20,31,32)$. The risk of infection is higher after emergency CS than after planned elective surgery (33). No common specific definition exists, but the diagnosis is usually based on the presence of signs of inflammation (swelling, tenderness and erythema) together with discharge of pus from the wound (34). Fever is not always present and lab tests tend to be unspecific, at least in early stages of disease. The most commonly found pathogens in cultures from infected wounds are groups A or B-hemolytic Streptococci, Staphylococcus aureus, Staphylococcus epidermidis and Ureaplasma urealyticum (35). In rare cases, WI can affect the underlying fascia and cause necrotizing fasciitis, which is a life-threatening infection with 
reported mortality rates between $30 \%$ and $60 \%$ (34). Necrotizing fasciitis is usually caused by group A beta-hemolytic streptococci, Staphylococcus aureus, anaerobic streptococci or Clostridium perfringens (34).

The risk of cesarean WI is higher among obese women (12). Diabetes mellitus is another risk factor, as well as long duration of the operation, high blood loss during surgery and high number of vaginal exams prior to an emergency CS (7, 36).

Infections in perineal wounds postpartum are less well studied, but obstetric anal sphincter injuries and episiotomies increase the risk of infection. The diagnosis is usually clinical, since an adequate culture can be difficult to obtain from these wounds.

\section{Mastitis}

Mastitis, or lactational mastitis, is the most common reported postpartum infection, affecting $2 \%$ to $33 \%$ of women (37-39). The nomenclature around these infections is not entirely clear in different studies. It is also an infection that in its milder states can be difficult to distinguish from milk stasis due to milk duct engorgement. Milk stasis, on the other hand can proceed to infectious mastitis, with breast abscess or sepsis as the ultimate states of disease $(34,37)$. Mastitis is characterized by signs of inflammation together with several days of high fever (37). Local swelling and tenderness of the breast can be signs of breast abscess. The pathogens found in these infections are almost always Staphylococcus aureus or group A or B streptococci (34). Obstetric risk factors for mastitis are sparsely described, whereas a history of mastitis, cracked nipples and university education have been reported to be associated with mastitis (39, 40). The diagnosis is usually clinical, with ultrasound used as the method of choice to rule out or confirm breast abscess.

\section{Urinary tract infection}

UTI is one of the most common bacterial infections requiring antibiotic treatment in Swedish outpatient care. Approximately half of all women acquire at least one urinary tract infection in life $(41,42)$. Around one out of eight women have an episode of UTI every year $(41,42)$. It is more common among younger age groups (41). Among delivered women $1.1 \%$ to $2.8 \%$ have been reported to acquire a UTI in the puerperium $(8,20)$.

Cystitis is the form of UTI where the infection involves mainly the urinary bladder. Common symptoms are dysuria, increased urinary frequency, urinary urgency and sometimes suprapubic tenderness $(34,43)$. Fever is sometimes present. 
In pyelonephritis, the kidneys are affected by the infection and in about one out of four cases there is also bacteremia. The yearly incidence of pyelonephritis among women has been estimated to be $0.39 \%$ to $2.4 \%$ (44). This type of infection causes more severe symptoms than cystitis, with high fever, flank pain and tenderness and sometimes deteriorated general condition (34).

The most common pathogens causing UTI among women of childbearing age are Escherichia coli and Staphylococcus saprophyticus (45). The diagnosis of cystitis is usually based on a combination of typical symptoms, dipstick positive for nitrite and / or leucocytes and a positive urine culture (46).

\section{Obesity}

WHO defines overweight and obesity as an abnormal or excessive fat accumulation that may impair health. For classification and comparison, the Body Mass Index (BMI) is commonly used (47). It is calculated by the individual's weight in kilograms divided by the square of its height in meters $\left(\mathrm{kg} / \mathrm{m}^{2}\right)$. Normal weight is defined as a BMI between 18.5 and $24.9(48)$. Different classifications for obesity have been used. WHO has used the terms Obesity classes I, II and III for BMI-groups 30-34.9, 35-39.9 and $\geq 40$. In this thesis, the following classifications of BMI-groups have been used:

Table 1. Classification of BMI-groups used in this thesis

\begin{tabular}{|l|l|}
\hline $\begin{array}{l}\text { BMI } \\
\left(\mathbf{k g} / \mathbf{m}^{\mathbf{2}}\right)\end{array}$ & Classification \\
\hline$<18.5$ & Underweight \\
\hline $18.5-24.9$ & Normal weight \\
\hline $25-29.9$ & Overweight \\
\hline $30-34.9$ & Obesity \\
\hline$\geq 35$ & Morbid obesity \\
\hline
\end{tabular}

The prevalence of overweight and obesity is increasing in almost every country in the world. Between the years 1975 and 2016 the prevalence of obesity in the world almost tripled. WHO estimates that more than 1.9 billion people in the world were overweight in 2016 and over 650 million of these were obese: 39\% of women over 18 years of age were overweight and $15 \%$ were obese (49). In the United States 36.5\% of women aged 20 to 39 were obese in 2016 (50) and the same year in Sweden $26 \%$ of pregnant women were overweight and $14 \%$ were obese (51). The prevalence of obesity among pregnant Swedish women has doubled since 1992 (Figure 1.). 
Figure 1. Proportions of overweight and obesity among women in Sweden at their first visit to antenatal care in the years 1992 to 2016. Source: The Swedish Medical Birth Register, National Board of Health and Welfare.

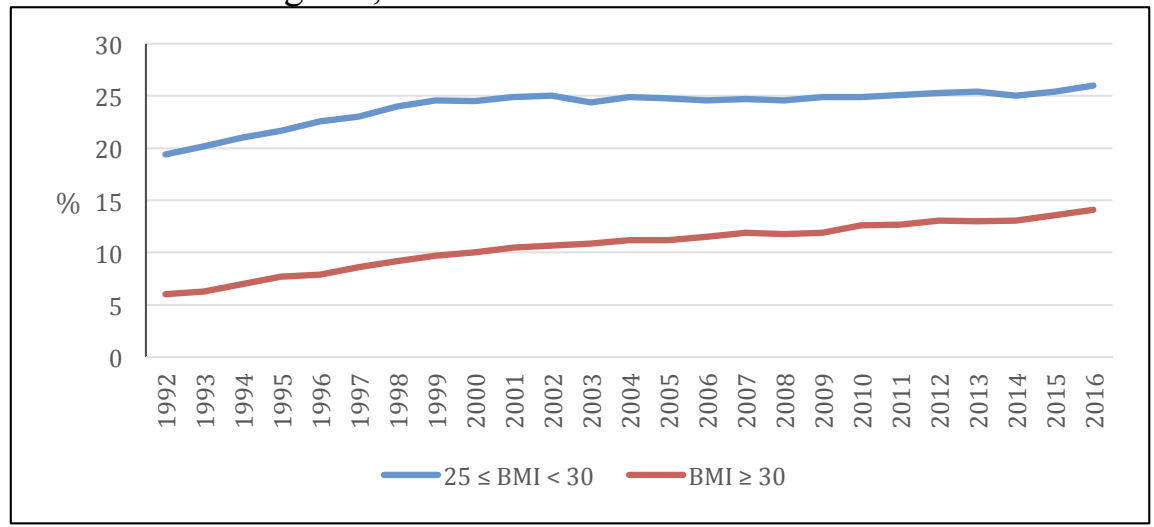

\section{Vitamin D}

The most well known effects of vitamin D in human homeostasis are the ones on bone health and bone mass. The major source of available vitamin $\mathrm{D}$ in the human body is 7-dehydrocholesterol, converted to vitamin D3 in keratinocytes in the skin, under exposure of ultraviolet B radiation from the sun. Vitamin D3 and vitamin D2 are also ingested with food, for example fungi (vitamin D2) and eggs and fish (vitamin D3) (52). Vitamin D3 is a prohormone, predominantly stored in adipocytes and liver cells. To obtain its active hormonal state, vitamin D3 is first hydroxylated in the liver to 25-hydroxyvitamin D (25OHD) by several different cytochrome P450 mixed-function oxidases (CYPs) with CYP2R1 as the major enzyme (53). In this form it circulates in the blood stream, predominantly bound to the vitamin D binding protein. A smaller proportion of 25OHD circulates bound to albumin or in its free form. To become the biologically active form of vitamin $\mathrm{D}, 1.25$-dihydroxyvitamin $\mathrm{D}, 25 \mathrm{OHD}$ undergoes a second hydroxylation, catalyzed by CYP27B1 mainly in the proximal tubules in the kidneys (54) (Figures 2 and 3).

The role of 1,25-dihydroxyvitamin $\mathrm{D}$ is of major importance in maintaining normal calcium levels in the body and in regulating parathyroid hormone levels. Its effect on calcium levels is primarily mediated via enhancement of the active cellular pathway in enterocytes, where calcium is absorbed from the intestine (53). 
Figure 2. Sources of vitamin D and the pathway of synthesis and hydroxylation to active 1.25 -dihydroxyvitamin $\mathrm{D}$ in the human body

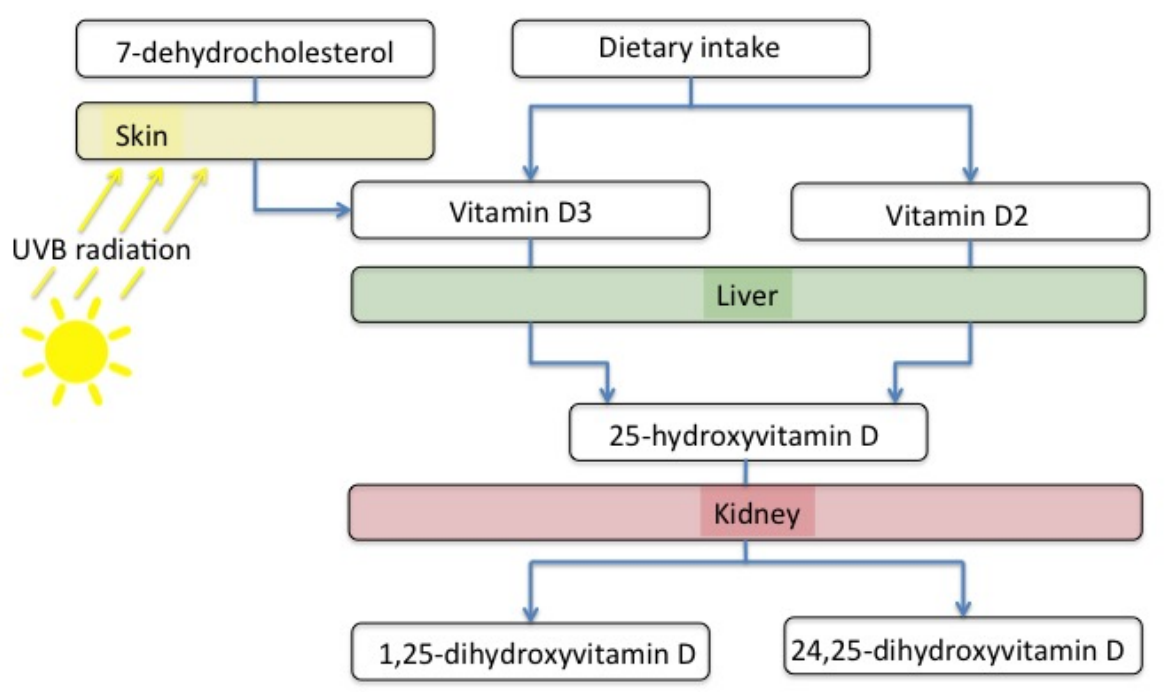

Figure 3. Molecular structures and principle of hydroxylation of vitamin D3 to 25-hydroxyvitamin D and 1.25-dihydroxyvitamin D

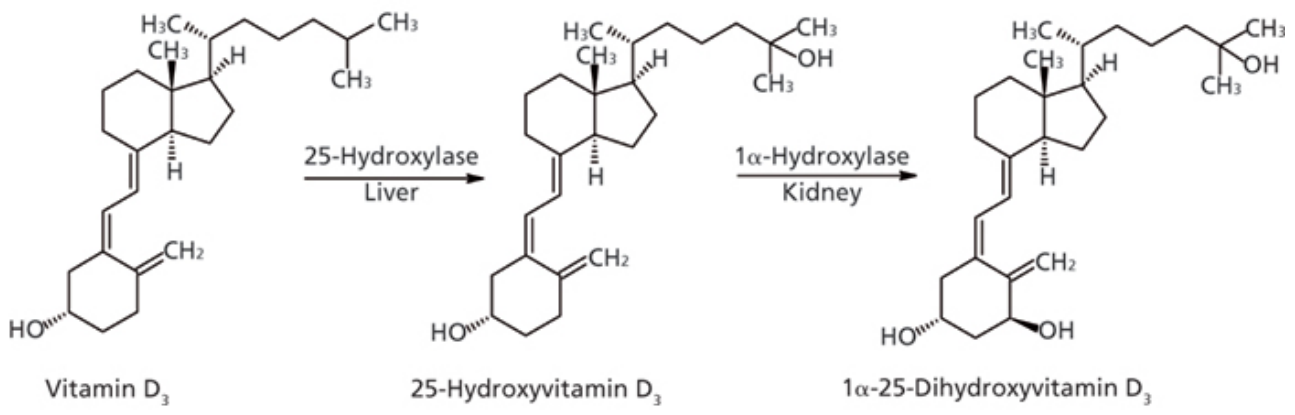


Vitamin D has been shown to be involved in several processes in the human immune system. As early as 1848 a clinical study on cod liver oil in the treatment of tuberculosis was conducted in London. The results from this study showed reduced progression of disease and mortality in the study group together with a significant weight gain (55). Another well-known example of historic use of vitamin $\mathrm{D}$ for the treatment of tuberculosis is when subjects with the disease were treated in specific sun-exposed locations (56). Furthermore, Niels Ryberg Finsen received the Nobel prize in medicine in 1903 for demonstrating that applying ultraviolet light to the skin could be used to treat lupus vulgaris, which is a cutaneous disease caused by Mycobacterium tuberculosis (57).

More recently, several epidemiological and experimental studies have pointed out vitamin D deficiency as a risk factor for several specific infectious diseases. Pathogens where the host's vitamin D status seems to play a role include Mycobacterium tuberculosis, Helicobacter pylori, Staphylococcus aureus, Pseudomonas aeruginosa, HIV, Hepatitis C virus, Respiratory syncytial virus and Influenza $(52,58)$.

Much effort has been applied to explain the role of vitamin D in the human immune system. Several different immune cells have been demonstrated to not only carry the vitamin D receptor, but also to be able to produce CYP27B1 and consequently to locally activate the hormone. Production of 1.25 dihydroxyvitamin $\mathrm{D}$ in the immune system has been shown to induce antimicrobial products such as cathelicin, which in turn can inhibit replication of Mycobacterium tuberculosis $(59,60)$.

Furthermore, epidemiological data shows that influenza infections in the world most commonly occur during the month after the winter solstice (61), when circulating vitamin D-levels are at their lowest. Virus infection incidence typically also peaks during winter, supporting the theory that an insufficient level of vitamin D increases the susceptibility to infection (62).

There is neither any international consensus about optimal vitamin D level nor about at what serum concentration of 25OHD the cut off for vitamin D insufficiency or deficiency should be. However, the most widely used definition for vitamin D deficiency seems to be $<50 \mathrm{nmol} / \mathrm{L}$, and for severe vitamin $\mathrm{D}$ deficiency $<25 \mathrm{nmol} / \mathrm{L}(52)$. For this thesis vitamin $\mathrm{D}$ deficiency was defined as plasma $25 \mathrm{OHD}$ level $<50 \mathrm{nmol} / \mathrm{L}$.

In a longitudinal study on pregnant Swedish women, one third were found to have vitamin D deficiency in the third trimester (63). Several studies have shown similar results, suggesting that vitamin D deficiency is common among pregnant women (64-66). 
In conclusion, postpartum infections are still a major factor related to maternal morbidity. In developing countries postpartum infections are a major cause of maternal mortality.

The prevalence of postpartum infections in Sweden is not known, and the impact of different factors on the risk of infection is diversely described.

Vitamin D has been shown to be important in the human defense against certain infections, but its role in postpartum infections has yet not been evaluated. 


\section{HYPOTHESES}

- Postpartum WI, endometritis, UTI or mastitis affects about one out of ten women in Sweden.

- Different maternal characteristics, mode of delivery and obstetric complications and interventions modify the risk of postpartum infection.

- Obesity is an independent risk factor of postpartum WI, endometritis and breast abscess, regardless of mode of delivery.

- Vitamin D deficiency is associated with a higher risk of overall infectious morbidity in the puerperium. 


\section{AIMS}

- To estimate the prevalence of postpartum WI, endometritis, UTI and mastitis in the southeast region of Sweden. Paper I.

- To evaluate the association between maternal characteristics, obstetrical interventions, pregnancy and delivery complications and postpartum WI, endometritis and UTI in term deliveries in Sweden. Paper II.

- To estimate the average time from delivery to the diagnosis of WI, endometritis and UTI among Swedish women after discharge from the delivery hospital. Paper II.

- To evaluate how the risk of postpartum WI, endometritis and breast abscess varies with maternal BMI after different modes of delivery. Paper III.

- To estimate the prevalence of vitamin D deficiency among Swedish women. Paper IV.

- To investigate whether vitamin D deficiency in pregnant women at the time of delivery is associated with a higher risk of postpartum infection. Paper IV. 


\section{MATERIAL AND METHODS}

A summary of the methodology in the four papers included in this thesis is presented in Table 2 .

Table 2. Summary of methodology in the papers in this thesis

\begin{tabular}{|c|c|c|c|c|}
\hline Paper & I & II & III & IV \\
\hline Design & $\begin{array}{l}\text { Population-based } \\
\text { observational } \\
\text { study }\end{array}$ & $\begin{array}{l}\text { Population-based } \\
\text { cohort study }\end{array}$ & $\begin{array}{l}\text { Population-based } \\
\text { cohort study }\end{array}$ & $\begin{array}{l}\text { Translational } \\
\text { cohort study }\end{array}$ \\
\hline Years & $2009-2010$ & $2005-2012$ & $2005-2012$ & 2014-2016 \\
\hline $\begin{array}{l}\text { Data } \\
\text { sources }\end{array}$ & $\begin{array}{l}\text { Questionnaire, } \\
\text { electronic medical } \\
\text { records }\end{array}$ & $\begin{array}{l}\text { MBR, NPR and } \\
\text { PDR }\end{array}$ & $\begin{array}{l}\text { MBR, NPR and } \\
\text { PDR }\end{array}$ & $\begin{array}{l}\text { Electronic } \\
\text { medical records } \\
\text { and biobank }\end{array}$ \\
\hline Subjects & $\begin{array}{l}6682 \text { delivered } \\
\text { women }\end{array}$ & $\begin{array}{l}795072 \text { term, } \\
\text { singleton } \\
\text { deliveries }\end{array}$ & $\begin{array}{l}841780 \text { singleton } \\
\text { deliveries }\end{array}$ & $\begin{array}{l}1397 \text { delivered } \\
\text { women }\end{array}$ \\
\hline Exposures & Delivery & $\begin{array}{l}\text { Maternal age, } \\
\text { parity, smoking in } \\
\text { early pregnancy, } \\
\text { BMI, mode of } \\
\text { delivery, } \\
\text { gestational age, } \\
\text { episiotomy, } \\
\text { obstetric anal } \\
\text { sphincter injury, } \\
\text { blood loss }>1000 \\
\text { ml, anemia }\end{array}$ & $\begin{array}{l}\text { Normal vaginal } \\
\text { delivery, } \\
\text { instrumental } \\
\text { vaginal delivery, } \\
\text { CS and maternal } \\
\text { BMI-class }\end{array}$ & $\begin{array}{l}\text { Serum levels of } \\
\text { vitamin D in } \\
\text { early labor }\end{array}$ \\
\hline $\begin{array}{l}\text { Outcome } \\
\text { measures }\end{array}$ & $\begin{array}{l}\text { Postpartum WI, } \\
\text { endometritis, UTI } \\
\text { and mastitis }\end{array}$ & $\begin{array}{l}\text { Postpartum WI, } \\
\text { endometritis and } \\
\text { UTI }\end{array}$ & $\begin{array}{l}\text { Postpartum WI, } \\
\text { endometritis and } \\
\text { breast abscess }\end{array}$ & $\begin{array}{l}\text { Postpartum } \\
\text { infections }\end{array}$ \\
\hline Covariates & & $\begin{array}{l}\text { Year of delivery, } \\
\text { maternal age, } \\
\text { parity and } \\
\text { smoking in early } \\
\text { pregnancy }\end{array}$ & $\begin{array}{l}\text { Year of delivery, } \\
\text { maternal age, } \\
\text { parity and } \\
\text { smoking in early } \\
\text { labor }\end{array}$ & $\begin{array}{l}\text { Parity, smoking } \\
\text { and mode of } \\
\text { delivery }\end{array}$ \\
\hline Statistics & $\begin{array}{l}\text { Chi-squared test } \\
\text { and Student's } t \text { - } \\
\text { test }\end{array}$ & Mantel-Haenszel & Mantel-Haenszel & $\begin{array}{l}\text { Univariable and } \\
\text { multivariable } \\
\text { logistic } \\
\text { regression } \\
\text { analyses }\end{array}$ \\
\hline
\end{tabular}

MBR $=$ The Swedish Medical Birth Register

NPR $=$ The Swedish National Patient Register

$\mathrm{PDR}=$ The Swedish Prescribed Drugs Register

$\mathrm{WI}=$ Wound infections

UTI $=$ Urinary tract infection 


\section{Study populations}

Paper I was a population-based study, where the population consisted of all delivered women in the southeast region of Sweden during one year, who agreed to answer the questionnaire. The responders in the study were compared to nonresponders, regarding maternal characteristics, blood loss and mode of delivery (Table 3).

Table 3. Comparison of responders and non-responders, regarding maternal characteristics, blood loss and mode of delivery (paper I)

\begin{tabular}{|l|l|l|l|}
\hline Maternal & Responders & Non-responders & \\
\hline Age, years & Mean $(\mathrm{n}=6,682)$ & Mean $(\mathrm{n}=4,442)$ & $\mathrm{p}$-value \\
\hline BMI, kg/m2 & 30.8 & 29.2 & $<0.05$ \\
\hline Parity & 24.9 & 25.2 & $<0.05$ \\
\hline Blood loss, ml & 482 & 0.94 & $<0.05$ \\
\hline Normal vaginal & 78 & 474 & n. s. \\
\hline delivery, \% & & 78.7 & n. s. \\
\hline Instrumental & 7.3 & 7.4 & n. s. \\
\hline delivery, \% & & 13.9 & n. s. \\
\hline Cesarean section, & 14.7 & & \\
\hline \% & & 14 & \\
\hline Induced labor \% & 12.8 & & \\
\hline
\end{tabular}

n. $\mathbf{s .}=$ not significant

In papers II and III the basis for the populations were all deliveries in Sweden that were registered in the MBR during 2005 to 2012. The study period was 
limited to these years due to the start of the PDR in 2005 and because 2012 was the latest year with complete data coverage at the time of data extraction. In paper II, the population was restricted to all term deliveries and in paper III all deliveries were studied. The study group in paper II was all term deliveries where there was a registered International Statistical Classification of Diseases and Related Health Problems - Tenth Revision (ICD-10) diagnosis code suggestive of WI, endometritis or UTI, and in paper III the study group consisted of all deliveries where there was a registered ICD-10 diagnosis code suggestive of WI, endometritis or breast abscess. The reference populations were considered as non-infected. Deliveries where the woman had been given an ICD-10 diagnosis code suggestive of another infection either in the MBR or the NPR were identified and excluded from the reference group. Similarly, the PDR was used to identify women with a filled drug prescription with ATC code J01 (antibiotics for systemic use) dated between 0 and 8 weeks postpartum. These women were also excluded. For comparison, in paper III aORs were also calculated with the whole population as reference. Maternal characteristics in relation to infections in paper II are presented in Table 4. 
Table 4. Maternal characteristics and number of infections in paper II (absolute numbers and percent)

\begin{tabular}{|c|c|c|c|c|c|}
\hline $\begin{array}{l}\text { Maternal } \\
\text { characteristics }\end{array}$ & $\begin{array}{l}\text { No infection } \\
n\end{array}$ & $\begin{array}{l}\text { Other } \\
\text { infection } \\
\text { diagnosis } \\
\text { and/or } \\
\text { dispensed } \\
\text { antibiotics n } \\
(\%) \\
\end{array}$ & $\begin{array}{l}\text { Wound } \\
\text { infections } \\
\mathrm{n}(\%)\end{array}$ & $\begin{array}{l}\text { Endometritis } \\
\mathrm{n}(\%)\end{array}$ & $\begin{array}{l}\text { Urinary } \\
\text { tract } \\
\text { infection } \\
n(\%)\end{array}$ \\
\hline \multicolumn{6}{|l|}{ Maternal age } \\
\hline$<20$ & $11032(1.6)$ & $1142(1.5)$ & $58(1.5)$ & $230(2.0)$ & $27(1.6)$ \\
\hline $20-24$ & 89845 (12.8) & $9393(12.4)$ & 441 (11.9) & $1758(15.1)$ & $199(12.0)$ \\
\hline $25-29$ & $\begin{array}{l}202903 \\
(28.9) \\
\end{array}$ & $\begin{array}{l}21485 \\
(28.3) \\
\end{array}$ & $973(26.3)$ & $3297(28.4)$ & $450(27.2)$ \\
\hline $30-34$ & $\begin{array}{l}246946 \\
(35.2)\end{array}$ & $\begin{array}{l}26925 \\
(35.4)\end{array}$ & $\begin{array}{l}1253 \\
(33.8)\end{array}$ & $3868(33.3)$ & $586(35.5)$ \\
\hline $35-39$ & $\begin{array}{l}125835 \\
(17.9)\end{array}$ & $\begin{array}{l}13927 \\
(18.3)\end{array}$ & $763(20.6)$ & $2028(17.5)$ & $312(18.9)$ \\
\hline $40-44$ & $24733(3.5)$ & $3002(3.9)$ & $203(5.5)$ & 414 (3.6) & $129(7.8)$ \\
\hline$\geq 45$ & $1141(0.2)$ & $154(0.2)$ & $14(0.4)$ & $24(0.2)$ & $56(3.4)$ \\
\hline \multicolumn{6}{|l|}{ Parity } \\
\hline 1 & $\begin{array}{l}305805 \\
(43.5)\end{array}$ & $\begin{array}{l}36493 \\
(48.0)\end{array}$ & $\begin{array}{l}2305 \\
(62.2)\end{array}$ & $5857(50.4)$ & $\begin{array}{l}1074 \\
(65.0)\end{array}$ \\
\hline 2 & $\begin{array}{l}263751 \\
(37.5)\end{array}$ & $\begin{array}{l}26424 \\
(34.8)\end{array}$ & $927(25.0)$ & $3812(32.8)$ & $393(23.8)$ \\
\hline 3 & $93828(13.4)$ & $9172(12.1)$ & $332(9.0)$ & 1346 (11.6) & $129(7.8)$ \\
\hline$\geq 4$ & $39051(5.6)$ & 3939 (5.2) & $141(3.8)$ & $684(5.2)$ & $56(3.4)$ \\
\hline \multicolumn{6}{|l|}{ Smoking } \\
\hline Unknown & 32467 (4.6) & $3517(4.6)$ & $170(4.6)$ & $567(4.9)$ & $101(6.1)$ \\
\hline None & $\begin{array}{l}624803 \\
(88.9)\end{array}$ & $\begin{array}{l}67729 \\
(89.1) \\
\end{array}$ & $\begin{array}{l}3189 \\
(86.1)\end{array}$ & 10291 (88.6) & $\begin{array}{l}1448 \\
(87.7)\end{array}$ \\
\hline$<10 /$ day & $34999(5.0)$ & $3624(4.8)$ & $234(6.3)$ & $581(5.0)$ & $82(5.0)$ \\
\hline$\geq 10 /$ day & $10166(1.4)$ & $1158(1.5)$ & $112(3.0)$ & $180(1.5)$ & $21(1.3)$ \\
\hline \multicolumn{6}{|l|}{ BMI } \\
\hline Unknown & $56695(8.1)$ & $6392(8.4)$ & 324 (8.7) & $1003(8.6)$ & $176(10.7)$ \\
\hline$<18.5$ & $15399(2.2)$ & $1617(2.1)$ & $72(1.9)$ & $252(2.2)$ & $31(1.9)$ \\
\hline $18.5-24.9$ & $\begin{array}{l}394320 \\
(56.1)\end{array}$ & $\begin{array}{l}41007 \\
(53.9)\end{array}$ & $\begin{array}{l}1603 \\
(43.3)\end{array}$ & 6034 (51.9) & $815(49.3)$ \\
\hline $25-29.9$ & $\begin{array}{l}160558 \\
(22.9)\end{array}$ & $\begin{array}{l}17899 \\
(23.5)\end{array}$ & $880(23.8)$ & $2838(24.4)$ & $402(24.3)$ \\
\hline $30-34.9$ & 53445 (7.6) & $6176(8.1)$ & $473(12.8)$ & $1037(8.9)$ & $155(9.4)$ \\
\hline$\geq 35$ & $22018(3.1)$ & $2937(3.9)$ & $353(9.5)$ & $455(3.9)$ & $73(4.4)$ \\
\hline Total & 702435 & 76028 & 3705 & 11619 & 1652 \\
\hline
\end{tabular}


At the time of planning study IV, there were delivery samples from 1400 women in the Pregnancy Biobank. A power calculation, described in the statistics section below, indicated a population size of 1243 women. To guarantee adequate sample analysis of enough samples, all 1400 women were included in the study. The inclusion in the Pregnancy Biobank is described below. Of the 1400 samples originally included in the study, one was excluded due to a registration error in the database and two were excluded since the sample contained whole blood instead of serum. The final population thus consisted of 1397 women.

\section{The southeast region of Sweden}

The study population in paper I was from the southeast region of Sweden, which consists of the three regions; Region Jönköping county, Region Kalmar county, and Region Östergötland (Figure 4). Seven hospitals in the southeast region of Sweden have delivery wards. In total, more than 12000 children are born annually in the region.

The seven delivery wards in the region work in close cooperation and most guidelines and routines are similar or the same between the wards. This facilitates mutual follow up and research. With few exceptions, all women in the region attend antenatal care and deliver in a hospital setting. In 2017 over 82\% of the deliveries in the region were vaginal, non-instrumental and $13 \%$ were CS.

Figure 4. Map of the six health care regions in Sweden. The southeast region is colored in pink.

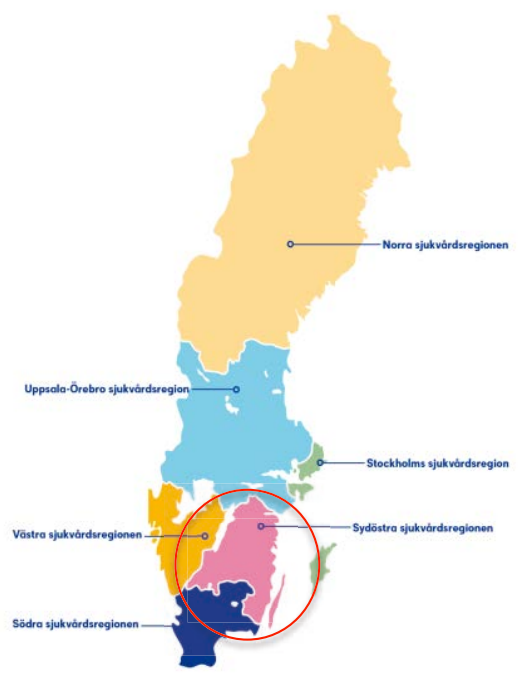




\section{Questionnaire and pilot study}

For paper I, a novel questionnaire was designed (appendix 1). The purpose was to evaluate the patient-reported prevalence of postpartum infections. The women were asked to report whether or not they had had endometritis, UTI, WI or mastitis within 2 months postpartum. They were also asked to report whether they had received antibiotic treatment for any of the infections, and in that case for what infection. Finally, they were asked to report any other infection during the same time.

The questionnaire, which contained a few questions on one page, was assessed concerning content validity by letting five co-workers at the Department of Obstetrics and Gynecology, University Hospital, Linköping and subsequently five randomly selected women at the maternity ward, University Hospital, Linköping, read the questionnaire and report on how they understood the questions. All ten persons reported that they understood it in a similar way and in the same way as the researchers.

In 2008 the questionnaire was used in a pilot study where all women delivered in the southeast region during February received the questionnaire. The total response rate in the pilot study without a reminder was high, which was used as a justification for not planning for reminders in the subsequent main study. The results from this pilot study are not published, but are reported in Table 6 in the Results section.

\section{The Swedish Medical Birth Register}

Following an act passed by the Swedish government, the MBR was established in 1973. It is mandatory for all delivery wards in Sweden to report defined data to the MBR and it contains data on over $98 \%$ of the deliveries in Sweden that have occurred since it started. These data has been evaluated three times; in 1976, 1988 and 2001. There are some missing data in the register, but errors and missing data are considered randomly distributed in the register, thus making it highly reliable for epidemiological studies (22). The MBR contains data about (italic text are examples, fat, italic text are data extracted for papers II and III.):

- Identification of patient

- Maternal and infant PIN

- Delivery hospital

- Social factors

- Occupation

○ Smoking in early pregnancy

- Maternal history

- Previous pregnancies and deliveries 


\section{○ Pre-pregnancy weight \\ ○ Height}

- Pregnancy

○ Expected date of delivery based on last menstrual period and sonography

○ Drugs used during pregnancy

- Delivery

- Pregnancy duration

- Presentation of infant

- Delivery diagnoses

- Operations at delivery

$\circ$ Induction of delivery

○ Episiotomy

- Infant

- Date and time of birth

- Stillborn/live-born

- Birth weight and birth length

○ Multiple birth

- Apgar scores

- Infant diagnoses

Data from the MBR was used in papers II and III.

\section{The Swedish National Patient Register}

The NPR (referred to as the Patient Register (PR) in paper II) was established in 1964 and has complete national coverage of all inpatient care since 1987 and outpatient specialist care since 2001 (23). Primary care visits are not reported to the NPR. Variables found in the register are: (italic text are examples, fat, italic text are data extracted for papers II and III.)

- Patient-related data
- PIN
- $\operatorname{Sex}$
- Age

- Caregiver

○ Hospital

- Type of department

- Administrative data

- Date of care (outpatients)

- Admission date

- Discharge date 
- Duration of admission

- Medical data

○ Primary diagnoses

- Additional diagnoses (1997-2009: 8 diagnoses, since 2010: unlimited)

- Procedures

Data from the NPR was used in papers II and III.

\section{The Swedish Prescribed Drugs Register}

The PDR was established in 2005 and has since then been widely used for pharmacoepidemiological research. It contains data about filled prescriptions of drugs according to the Anatomical Therapeutic Chemical classification system (ATC). In Sweden, a prescription is required for all preparations of antibiotics. Information about the indication for the prescription is not included in the PDR (24). The PDR contains data about: (italic text are examples, fat, italic text are data extracted for papers II and III.)

- Patient identification

○ PIN

- $\operatorname{Sex}$

- The drug

- ATC code

- Drug name

- Prescription

○ Amount prescribed

- Date of prescription

- Date of dispensation

- Cost

- Prescriber

- Clinic

- Prescribers profession

- Prescribers specialty

Data from the PDR was used in papers II and III. 
Figure 5. Flow chart of registers used in papers II and III

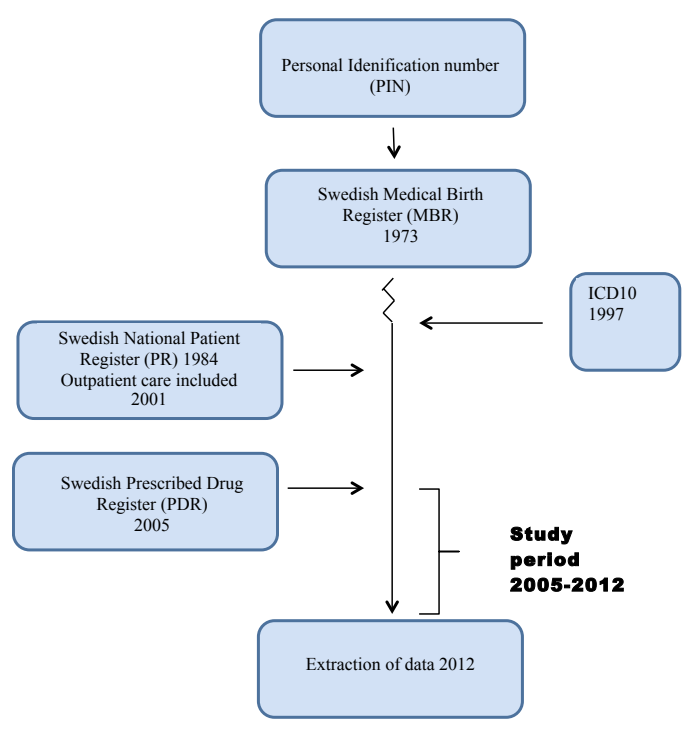

\section{Register Data extraction and combination}

For complete coverage of all three registers, all births during the period 2005 to the time of data extraction (2012), and that were registered in the MBR were identified. The three registers were further linked using the women's personal identification numbers. The National Board of Health and Social welfare replaced these identification numbers with unique but unidentifiable numbers, which were subsequently used for further linkage between the registers. Available data on infection diagnoses and drug dispensations for these women were then extracted from the NPR and the PDR. For the purpose of this study, data from the NPR and the PDR was restricted to 0-8 weeks postpartum.

\section{The Pregnancy Biobank}

The purpose of the Pregnancy Biobank (GRABB, Swedish:

Graviditetsbiobanken, register number 185) at the Department of Obstetrics and Gynecology, Region Östergötland, Sweden, is to facilitate research on pregnancy-related questions. It holds blood samples from over 8000 pregnant women (Table 5). Women were invited to participate in the project at their first visit to the antenatal clinic between weeks 6 and 10. After having received written consent from the women blood samples (one EDTA tube and one serum gel tube) were drawn in early pregnancy (weeks 8-11) during the second 
trimester (week 25) and early during labor. After written consent from both the woman and the partner, blood was also sampled from the umbilical cord (one EDTA-tube).

Maternal samples were centrifuged within one hour after sampling and aliquoted. The fractions obtained and stored from each sampling of maternal blood were (Figure 6):

- Six tubes with 0.2 to $0.5 \mathrm{ml}$ of plasma each (EDTA)

- One tube with up to $1.5 \mathrm{ml}$ of whole blood (EDTA)

- Three tubes with 0.2 to $0.5 \mathrm{ml}$ of serum

Umbilical cord samples were equally handled and 6 tubes with 0,2 to $0,5 \mathrm{ml}$ of plasma was stored (Figure 7). The samples were stored at -70 degrees Celsius. Inclusions to the biobank started 2011-03-21 and ended 2018-05-31. The first labor-sample was drawn 2014-04-01.

Table 5. Numbers of samples from the different sampling occasions in the pregnancy biobank

\begin{tabular}{|l|c|}
\hline Sampling occasion & $\begin{array}{c}\text { Total number of samples } \\
\text { in the biobank }\end{array}$ \\
\hline 1st trimester & 8015 \\
\hline 2nd trimester & 6340 \\
\hline Early labor & 2443 \\
\hline Umbilical cord & 3618 \\
\hline
\end{tabular}

There are complete samples (four occasions) from 1491 pregnancies in the biobank. From 3223 pregnancies there are both 2 nd trimester and umbilical cord samples.

Figure 6. Maternal samples included in the Pregnancy Biobank from each sampling occasion

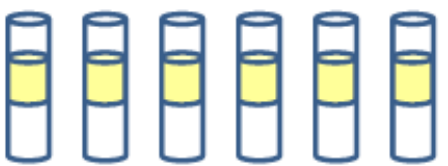

Plasma: $0.2-0.5 \mathrm{ml} / \mathrm{tube}$

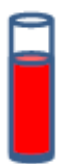

Blood: up to $1.5 \mathrm{ml} /$ tube Serum: $0.2-0.5 \mathrm{ml} /$ tube

Figure 7. Umbilical cord samples stored in the Pregnancy Biobank

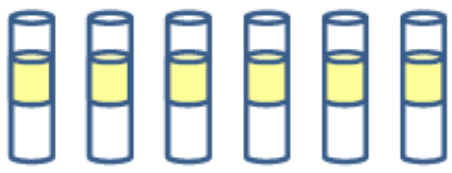

Plasma $0.2-0.5 \mathrm{ml} /$ tube 


\section{Analysis of Vitamin D}

25OHD was analyzed from serum samples at the accredited laboratory at the Department of Clinical Chemistry, Linköping University Hospital (SWEDAC 1342). The method used was the LIASION ${ }^{\circledR} 25$ OH Vitamin D TOTAL Assay, which is a direct competitive chemiluminescent immunoassay technology for the quantitative determination of total 25OHD. The samples were coded with a project-specific code and transported frozen to the laboratory where they were thawed, mixed and moved to specific cartridges. During the first incubation, $25 \mathrm{OHD}$ was dissociated from its binding protein and bound to the specific antibody on the solid phase. After 10 minutes the tracer (vitamin D linked to an isoluminol derivate) was added. After a second 10-minute incubation, the unbound material was removed with a wash cycle. Subsequently, the starter reagents were added to initiate a flash chemiluminescent reaction. The light signal was measured by a photomultimeter as relative light units and was inversely proportional to the concentration of $25 \mathrm{OHD}$ in the sample. The results from the analyses were reported in a Microsoft Excel-sheet with sample codes and concentrations of $25 \mathrm{OHD}$ expressed as $\mathrm{nmol} / \mathrm{L}$. 
Figure 8. Picture of stored maternal serum samples in the Pregnancy Biobank, taken during manual remarking of samples before analysis of vitamin D concentrations.

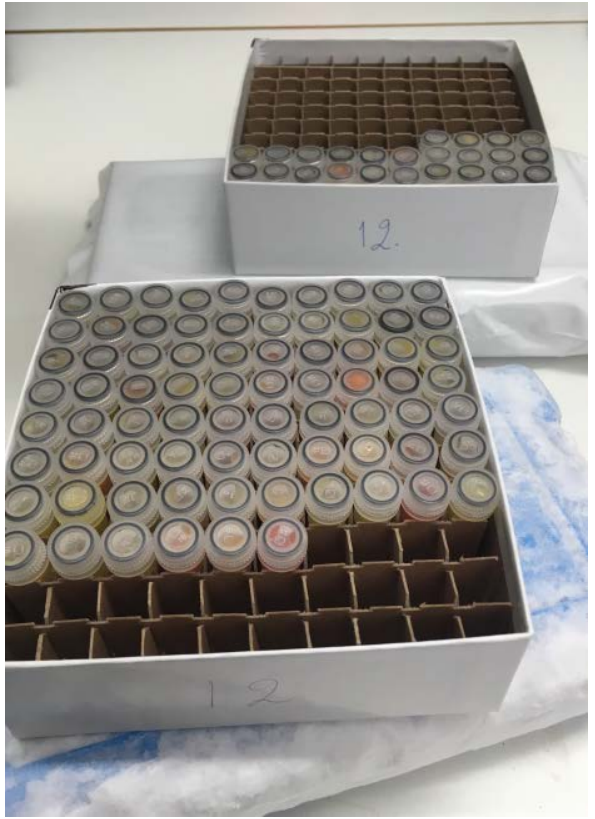

Figure 9. Picture of the vitamin D analysis instrument (LIAISON ${ }^{\circledR} \mathrm{XL}$ ) at the laboratory at the Department of Clinical Chemistry, Linköping University Hospital during analysis of samples included in paper IV.

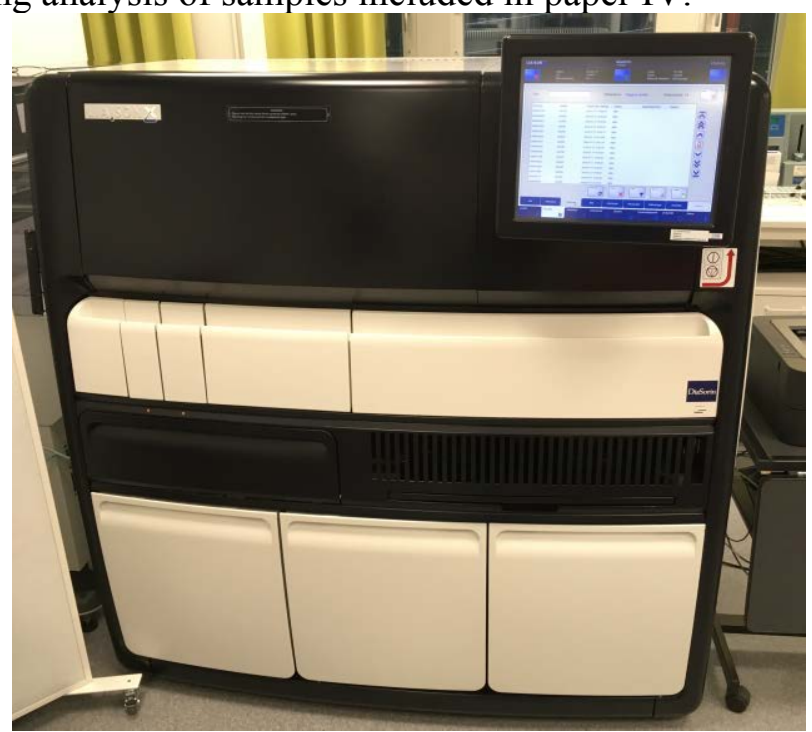




\section{Statistics}

In paper I, which was an observational study with questionnaires, responders were compared to non-responders by using a chi-squared test. The prevalences of infections in different counties were compared using a chi-squared test and a Student's $t$-test. Univariable logistic regression analysis was used to calculate crude odds ratios (non-published data). Calculations were made by using SAS software v. 9.2 (SAS Institute, Cary, NC, USA).

In papers II and III the Mantel-Haenszel technique was used to estimate adjusted odds ratios, and $95 \%$ confidence intervals were determined using a test-based method based on the Mantel-Haenszel chi-squared test (67). The MantelHaenszel analyses were run using programs, written ad hoc.

The size of the population in Paper IV was based on a power calculation with the assumption that vitamin D deficiency would be associated with a $50 \%$ increased risk of postpartum infection $(63,68,69)$. With alpha 0.05 and beta 0.8 a difference should then be revealed with 1243 women in the study.

Data analysis was performed using the Statistical Package for the Social Sciences (SPSS Inc., Chicago, IL, USA) version 25. Maternal characteristics were investigated using chi-squared tests for categorical variables and Student's $t$-tests for numerical variables. Obstetric variables were entered in univariable and multivariable logistic regression analyses. Crude and adjusted odds ratios were calculated with $95 \%$ confidence intervals. All analyses were two-sided and p-values less than 0.05 were considered as statistically significant.

\section{Ethics}

The regional Ethical Review Board in Linköping approved the studies (Table 6).

Table 6. Overview of ethical approvals for the studies included in this thesis

\begin{tabular}{|c|c|}
\hline Paper & $\begin{array}{c}\text { Registration number of } \\
\text { ethical approval }\end{array}$ \\
\hline I & M44-09 \\
\hline II & $2014 / 319-32$ \\
\hline III & $2014 / 319-32$ \\
\hline IV & $2017 / 401-31$ \\
\hline
\end{tabular}

In the first study, non-responders were compared to the responders. The women's PINs were replaced with code numbers and no data could be linked to a unique individual by the researchers. The purpose of this methodology was to determine whether the results were generalizable. 
In the second and third studies large numbers of women were included and no PINs were distributed to the researchers. The results cover many variables and may be of importance for women in the future.

In the fourth study samples from a biobank were used. The women gave written consent to use the samples for future research on pregnancy-related topics. 


\section{RESULTS}

\section{Pilot study to paper I}

The main study was preceded by a pilot study in 2008. In that study, 620 out of 799 delivered women $(78 \%)$ answered the questionnaire. The results regarding prevalence are presented in Table 7.

Table 7. Proportions of women who responded yes to the questions in the questionnaire in the pilot study preceding the study for paper I.

\begin{tabular}{|l|c|c|}
\hline & $\begin{array}{c}\text { Answered } \\
\text { "yes" (\%) }\end{array}$ & $\begin{array}{c}\text { Answered "yes" and } \\
\text { received antibiotics (\%) }\end{array}$ \\
\hline Any infection $^{\mathrm{a}}$ & 12.3 & $7.4 \%$ \\
\hline Wound infection & 1.9 & 0.8 \\
\hline Urinary tract infection & 2.9 & 2.4 \\
\hline Endometritis & 2.6 & 2.3 \\
\hline Mastitis & 4.4 & 2.7 \\
\hline
\end{tabular}

${ }^{\mathrm{a}}$ wound infection, urinary tract infection, endometritis or mastitis

In the pilot study, an inter-regional comparison of infection prevalence was conducted. The prevalence of antibiotic-treated infection was higher in Region Östergötland (12.1\%) than in Region Jönköping county (4.5\%) and Region Kalmar county $(4.3 \%), \mathrm{p}<0.001$.

\section{Paper I}

During the study period, 11124 women gave birth in the southeast region. The questionnaire was sent to all women with a valid address (>99\%). The questionnaire was answered and returned by 6682 women (60.1\%). At least one infection postpartum was reported by 690 women (10.5\%). In total, 770 different postpartum infections were reported. In the study population, 501 (7.5\%) of women reported antibiotic treatment for postpartum infection. The total number of antibiotic-treated infections was 550.

The prevalence of the specific infections without and with antibiotic treatment is presented in Figure 10. 
Figure 10. Prevalence of postpartum infections in southeast Sweden.

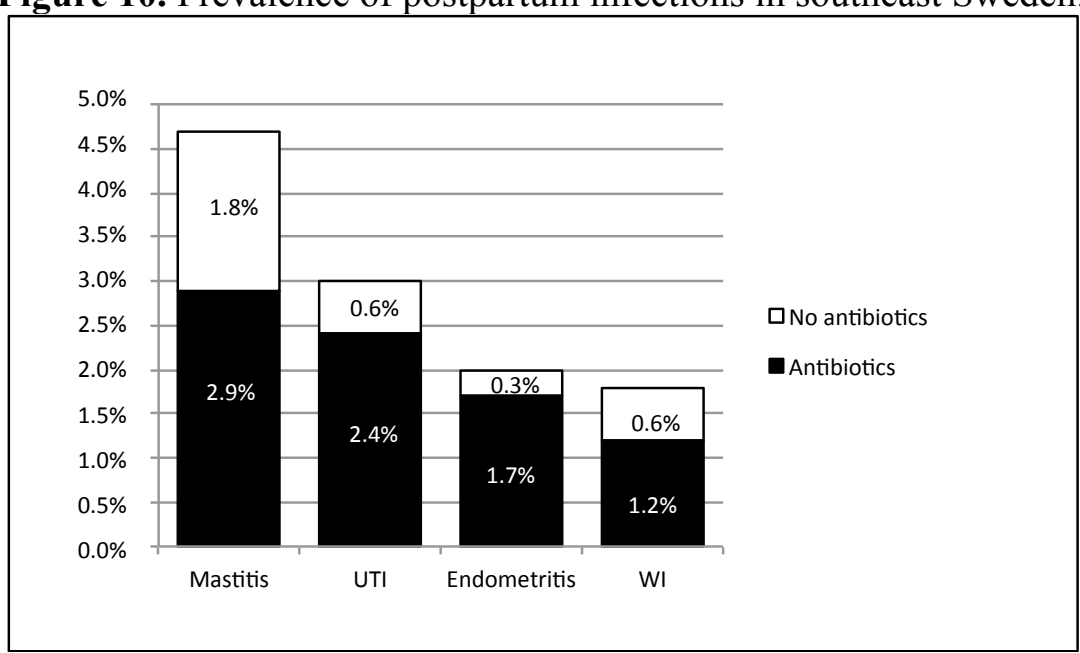

$\mathrm{UTI}=$ urinary tract infection, $\mathrm{WI}=$ wound infections

The study also evaluated inter-county differences in postpartum infection prevalence. No significant difference was found (Figure 11). However, endometritis was more commonly reported after deliveries at the University Hospital in Linköping than in the rest of the southeast region.

Detailed information about response rate and prevalence of infections is presented in Table 8 .

Figure 11. Prevalence of postpartum infections, with and without antibiotic treatment, in the different regions in southeast Sweden.

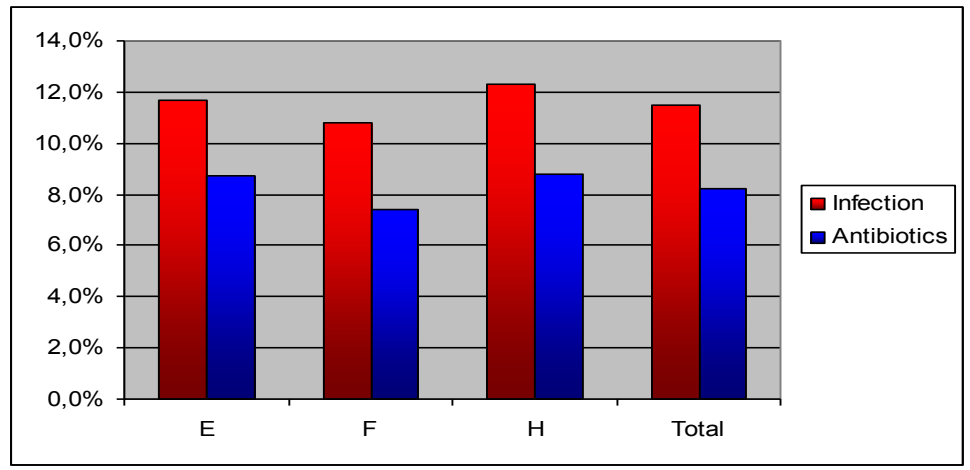

E: Region Östergötland. F: Region Jönköping county. H: Region Kalmar county. 
Table 8. Number and percentage of responders and postpartum infections with and without antibiotic treatment

\begin{tabular}{|c|c|c|c|c|c|c|}
\hline & & Responders & $\begin{array}{l}\text { Mastitis / Antibiotic } \\
\text { treated Mastitis }\end{array}$ & $\begin{array}{l}\text { UTI / Antibiotic } \\
\text { treated UTI }\end{array}$ & $\begin{array}{l}\text { Endometritis / } \\
\text { Antibiotic treated } \\
\text { Endometritis }\end{array}$ & $\begin{array}{l}\text { WI / Antibiotic } \\
\text { treated WI }\end{array}$ \\
\hline County & Hospital & $\mathrm{n}(\%), \mathrm{p}<0,05$ & n (\%), n. s. & n (\%), n.s. & n (\%), n. s. & n (\%), n.s. \\
\hline \multirow[t]{3}{*}{ Östergötland } & University Hospital, Linköping & $1,635(62.1)$ & $62(3.8) / 43(2.6)$ & $57(3.5) / 46(2.8)$ & $47(2.9) / 38(2.3)$ & $30(1.8) / 20(1.2)$ \\
\hline & Vrinnevi Hospital, Norrköping & $1,357(58.6)$ & $64(4.7) / 40(2.9)$ & $39(2.9) / 31(2.3)$ & $19(1.4) / 19(1.4)$ & $33(2.4) / 23(1.7)$ \\
\hline & County of Östergötland, Total & $2,992(60.5)$ & $126(4.2) / 83(2.8)$ & $96(3.2) / 77(2.6)$ & $66(2.2) / 57(1.9)$ & $63(2.1) / 43(1.4)$ \\
\hline \multirow[t]{4}{*}{ Jönköping } & Highland Hospital, Eksjö & $566(57.8)$ & $28(4.9) / 14(2.5)$ & $14(2.5) / 10(1.8)$ & $12(2.1) / 10(1.8)$ & $9(1.6) / 6(1.1)$ \\
\hline & Ryhov County Hospital, Jönköping & $1,293(64.3)$ & $62(4.8) / 32(2.5)$ & $30(2.3) / 24(1.9)$ & $20(1.5) / 19(1.5)$ & $24(1.9) / 16(1.2)$ \\
\hline & Värnamo Hospital & $534(62.9)$ & $27(5.1) / 17(3.2)$ & $16(3.0) / 14(2.6)$ & $9(1.7) / 8(1.5)$ & $8(1.5) / 6(1.1)$ \\
\hline & County of Jönköping, Total & $2,393(62.4)$ & $117(4.9) / 63(2.6)$ & $60(2.5) / 48(2.0)$ & $41(1.7) / 37(1.5)$ & $41(1.7) / 28(1.2)$ \\
\hline \multirow[t]{3}{*}{ Kalmar } & Kalmar County Hospital & $834(55.9)$ & $41(4.9) / 27(3.2)$ & $32(3.8) / 28(3.4)$ & $18(2.2) / 16(1.9)$ & $8(1.0) / 6(0.7)$ \\
\hline & Västervik Hospital & $463(54.7)$ & $32(6.9) / 21(4.5)$ & $13(2.8) / 7(1.5)$ & $8(1.7) / 6(1.3)$ & $8(1.7) / 3(0.6)$ \\
\hline & County of Kalmar, Total & $1,297(55.5)$ & $73(5.6) / 48(3.7)$ & $45(3.5) / 35(2.7)$ & $26(2.0) / 22(1.7)$ & $16(1.2) / 9(0.7)$ \\
\hline
\end{tabular}

During the study period prophylactic antibiotics was given perioperatively to all women undergoing emergency CS in the region. For planned, elective CS, antibiotic prophylaxis was only given at the delivery wards in Eksjö and in Västervik. In the total material, CS was a risk factor for postpartum infection. For emergency CS the OR was 2.46 (95\% CI 1.35-2.66). For planned, elective CS the OR was 1.9 (95\% CI 1.37-2.65). When planned, elective CS was compared between the two units that used prophylactic antibiotics and the five units that did not, a lower risk of postpartum infections was found when prophylactic antibiotics were given perioperatively, OR 0.31 (95\% CI 0.11 0.89 ). This did not change when only antibiotic-treated infections were included in the calculations, OR 0.22 (95\% CI 0.05-0.92).

Manual placental removal and postpartum hemorrhage $>1000 \mathrm{ml}$ were both risk factors for endometritis, ORs 3.28 (95\% CI 1.56-6.89) and 3.11 (95\% CI 1.905.09) respectively.

For quality control a subgroup of women that gave birth at Ryhov County Hospital and reported antibiotic treatment for endometritis was identified. The subgroup's patient records were screened to confirm the infections, and that the correct codes were registered.

For 18 women reporting antibiotic-treated endometritis, evidence was found in the records that $16(89 \%)$ had received antibiotics for endometritis. The other two had both received antibiotics for WI. Five (31\%) of 16 records were correctly coded. Two (11\%) cases of endometritis were diagnosed before discharge. 


\section{Paper II}

In paper II, maternal and obstetric risk factors for postpartum infections were evaluated. Risk factors were referred to as "factors associated with infection". In this thesis, however, those factors were called "risk factors".

The study population consisted of 582576 women who had 795072 term deliveries during the years 2005 to 2012. Among these deliveries 16976 were complicated by WI, endometritis or UTI in the postpartum period. Endometritis was the most commonly registered diagnosis, followed by WI, while UTI was the least commonly registered diagnosis. The reference group consisted of 702 072 deliveries without any registered ICD-10 code suggestive of infection or any filled prescription of antibiotics.

Figure 12. Flow chart of the inclusion process

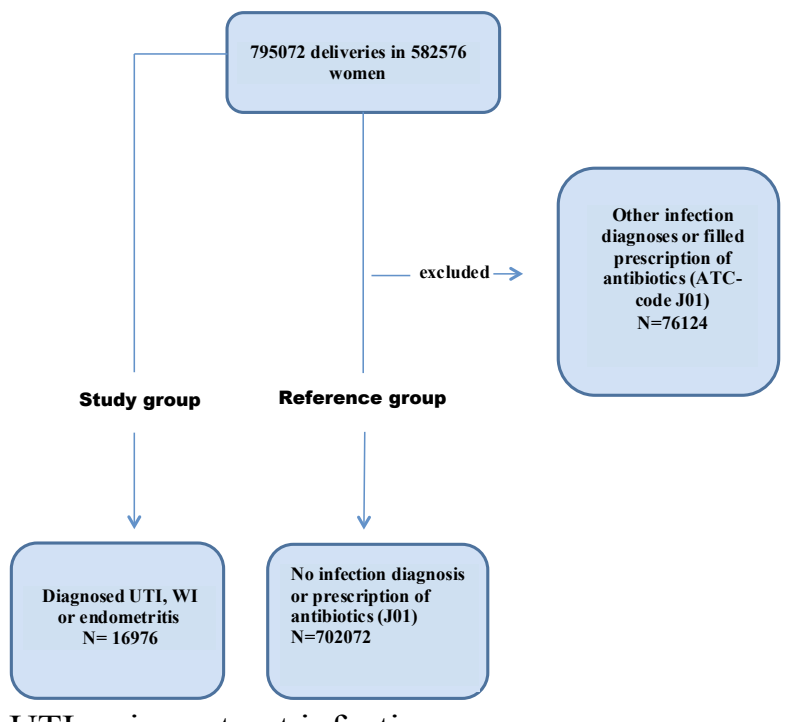

UTI: urinary tract infection

WI: wound infection

Data source of the ICD-10 codes of postpartum infections are presented in Table 9. Diagnoses of WI were found in the MBR in $20 \%$ of cases. For UTI and endometritis these figures were $84 \%$ and $16 \%$ respectively. 
Table 9. Data sources of the infections in paper II

\begin{tabular}{|lllrrr|}
\hline MBR & $\begin{array}{l}\text { PR } \\
\text { Inpatient } \\
\text { diagnosis }\end{array}$ & $\begin{array}{l}\text { PR } \\
\text { Outpatient } \\
\text { diagnosis }\end{array}$ & $\begin{array}{l}\text { Wound } \\
\text { infection }\end{array}$ & $\begin{array}{l}\text { Urinary } \\
\text { tract } \\
\text { infection }\end{array}$ & $\begin{array}{l}\text { Endo- } \\
\text { metritis }\end{array}$ \\
\hline No & No & Yes & 2395 & 109 & 6040 \\
\hline No & Yes & No & 377 & 150 & 3054 \\
\hline No & Yes & Yes & 184 & 3 & 633 \\
\hline Yes & No & No & 369 & 1254 & 984 \\
\hline Yes & No & Yes & 78 & 0 & 85 \\
\hline Yes & Yes & No & 243 & 135 & 740 \\
\hline Yes & Yes & Yes & 59 & 1 & 83 \\
\hline Total & & & 3705 & 1652 & 11619 \\
\hline
\end{tabular}

MBR: The Swedish Medical Birth Register

PR: The Swedish National Patient Register

Among maternal characteristics, the risk of WI was higher the older the woman, if she was primiparous, smoked in early pregnancy and if she was overweight or obese. For endometritis, being younger than 25 years, primiparous and overweight or obese were all risk factors. Women over 29 years of age, primiparous and overweight or obese women had an increased risk of UTI.

Regarding obstetric events and complications, almost every studied factor that was not considered as normal was a risk factor for postpartum infection. For WI, the highest aORs were found after CS, aOR 17.2 (95\% CI 16.1-18.3) obstetric anal sphincter injuries aOR 10.7 (95\% CI 9.80-11.9) and episiotomy aOR 10.2 (95\% CI 8.94-11.5). For endometritis, anemia aOR 3.16 (95\% CI 3.01-3.31), manual placental removal aOR 2.72 (95\% CI 2.51-2.95) and emergency CS aOR 2.72 (95\% CI 2.59-2.85) were the strongest risk factors. Anemia was also the factor that increased the risk of UTI the most aOR 3.98 (95\% CI 3.57-4.43), followed by vacuum extraction aOR 3.70 (95\% CI 3.294.16) and emergency CS aOR 3.46 (95\% CI 3.07-3.89).

Premature delivery was a risk factor for all three studied infections, WI: aOR 1.84 (95\% CI 1.65-2.07), endometritis: aOR 1.43 (95\% CI 1.33-1.54), UTI: aOR 2.80 (95\% CI 2.43-3.23) and the aORs were two to six times higher if the prematurity was associated with chorioamnionitis.

In this study, the average time from delivery to diagnosed infection (peak occurrence) was also estimated. For the purpose of these calculations only data from the NPR was used. The MBR does not provide information about date of diagnosis. The peak occurrence after hospital discharge of UTI was six days post-delivery, while for endometritis and WI the peak occurrence was seven days post-delivery (Figure 13). 
Figure 13. Number of days from delivery to infection diagnosed in a hospital or in an outpatient specialist setting. Data for the first 30 days postpartum are presented. Diagnoses from the referral for delivery are excluded, as the exact date of diagnosis cannot be determined. Altogether 14369 out of the total 16976 diagnoses were available for analysis. The data are presented as the percentage of the total number of infections per day postpartum.

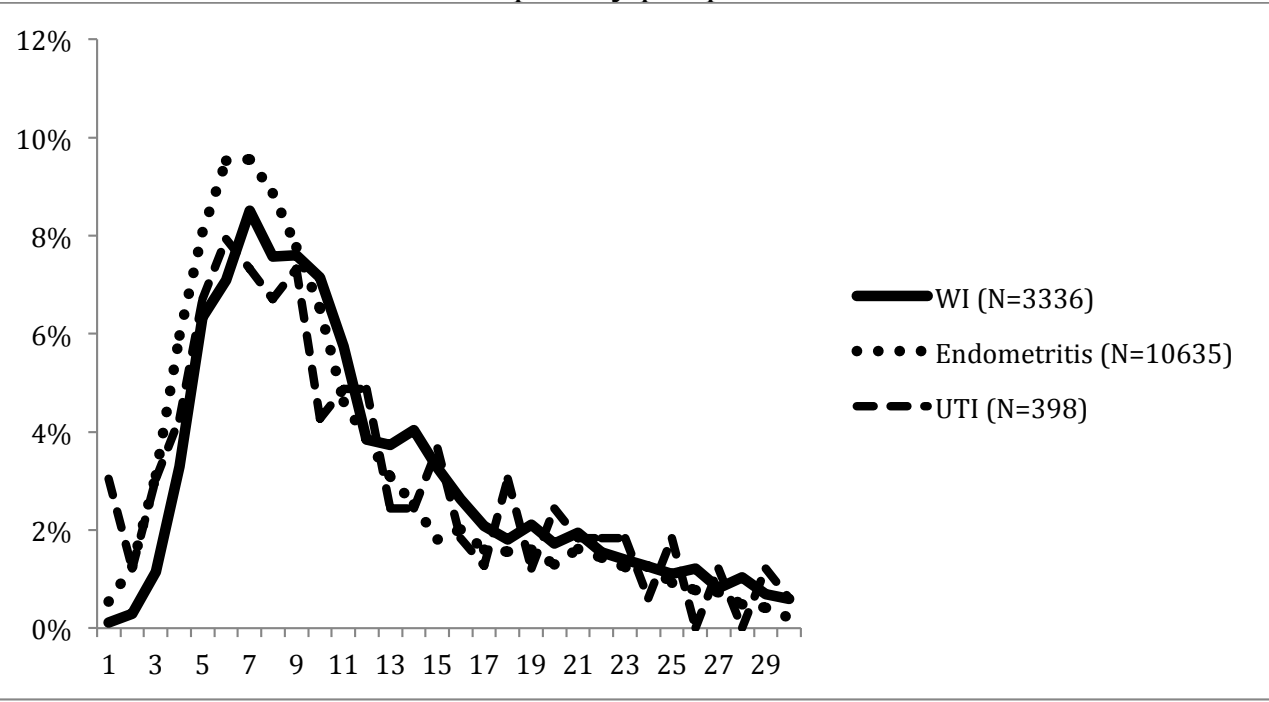

For further analysis of peak occurrence, the dates of the first prescription of antibiotics after delivery were extracted from the PDR. Diagrams of the number of prescriptions in relation to date of delivery are shown below (Figure 14). These data were not published, but they support the findings regarding peak occurrence. 
Figure 14. Number of days from delivery to dispensation of prescribed Pivmecillinam, Flucloxacillin, Penicillins with extended spectrum, Betalactamase sensitive penicillins, Cephalosporins and Beta-lactamase resistant penicillins.
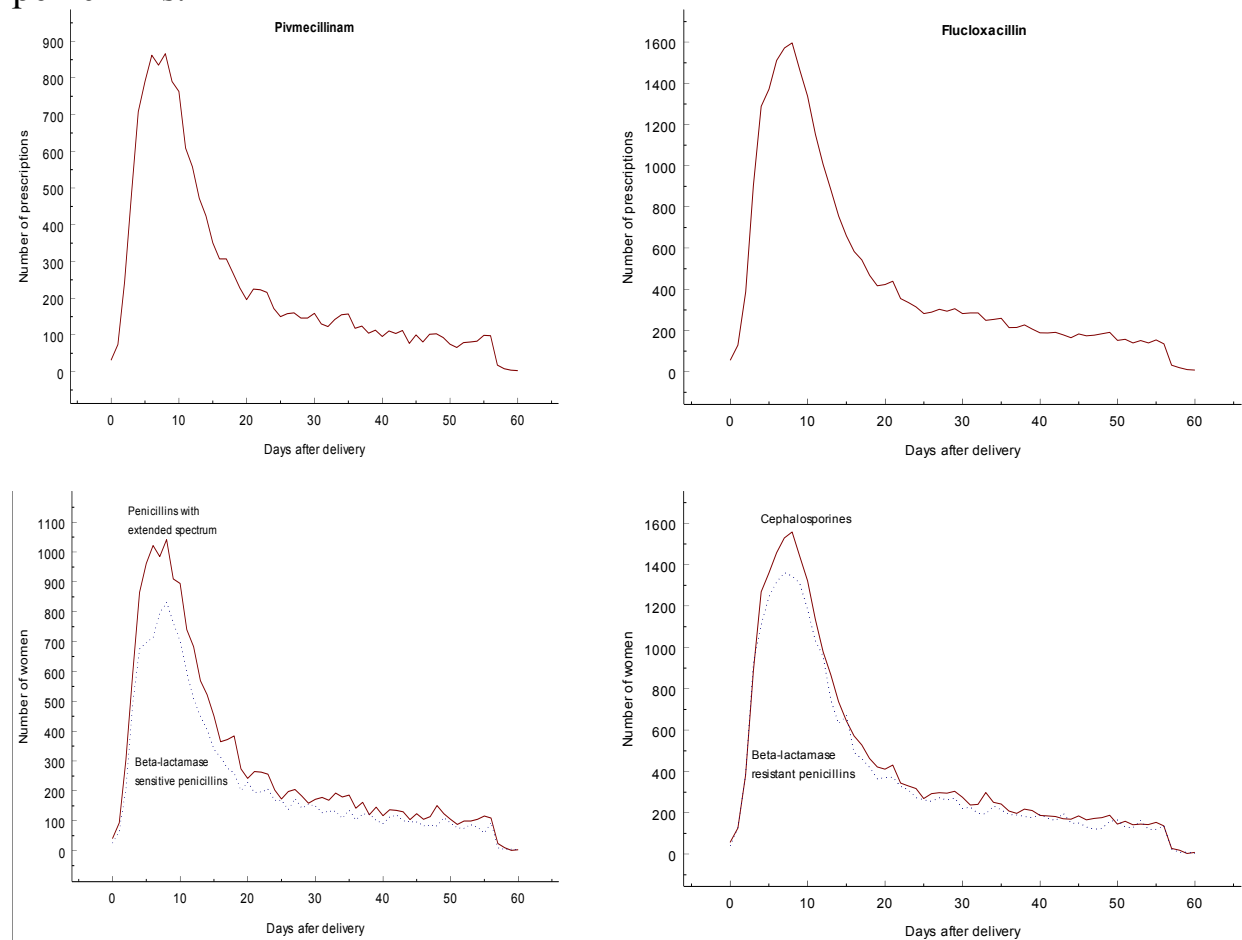


\section{Papers I+II}

From the calculations on risk of postpartum infections in papers I and II, a comparison is shown in table 10.

Table 10. Comparison between paper I and paper II regarding ORs for postpartum infections after different obstetric complications. Note that ORs in paper I are crude, while aORs in paper II are adjusted for maternal age, parity, smoking in early pregnancy and BMI.

\begin{tabular}{|c|c|c|c|c|c|c|}
\hline \multirow{2}{*}{$\begin{array}{l}\text { Independent } \\
\text { variable }\end{array}$} & \multicolumn{3}{|l|}{ Paper I } & \multicolumn{3}{|l|}{ Paper II } \\
\hline & $\begin{array}{l}\text { Wound } \\
\text { infection }\end{array}$ & $\begin{array}{l}\text { Urinary } \\
\text { tract } \\
\text { infection }\end{array}$ & Endometritis & $\begin{array}{l}\text { Wound } \\
\text { infection }\end{array}$ & $\begin{array}{l}\text { Urinary } \\
\text { tract } \\
\text { infection }\end{array}$ & Endometritis \\
\hline & $\begin{array}{l}\text { OR } \\
(95 \% \\
\text { CI) }\end{array}$ & $\begin{array}{l}\text { OR } \\
(95 \% \\
\text { CI })\end{array}$ & $\begin{array}{l}\text { OR }(95 \% \\
\text { CI) }\end{array}$ & $\begin{array}{l}\text { aOR } \\
(95 \% \\
\mathrm{CI})\end{array}$ & $\begin{array}{l}\mathrm{aOR} \\
(95 \% \\
\mathrm{CI})\end{array}$ & $\begin{array}{l}\text { aOR }(95 \% \\
\mathrm{CI})\end{array}$ \\
\hline $\begin{array}{l}\text { Preterm } \\
\text { delivery }\end{array}$ & $\begin{array}{l}1.43 \\
(0.62- \\
3.31)\end{array}$ & $\begin{array}{l}1.34 \\
(0.72- \\
2.50)\end{array}$ & $\begin{array}{l}0.81(0.33- \\
2.00)\end{array}$ & $\begin{array}{l}1.84 \\
(1.65- \\
2.07)^{\mathrm{a}}\end{array}$ & $\begin{array}{l}2.80 \\
(2.43- \\
3.23)^{\mathrm{a}}\end{array}$ & $\begin{array}{l}1.43(1.33- \\
1.54)^{\mathrm{a}}\end{array}$ \\
\hline $\begin{array}{l}\text { Post-term } \\
\text { delivery }\end{array}$ & $\begin{array}{l}0.98 \\
(0.35- \\
2.69) \\
\end{array}$ & $\begin{array}{l}1.52 \\
(0.83- \\
2.76) \\
\end{array}$ & $\begin{array}{l}1.18(0.54- \\
2.55)\end{array}$ & $\begin{array}{l}1.59 \\
(1.43- \\
1.77)^{\mathrm{a}} \\
\end{array}$ & $\begin{array}{l}1.51 \\
(1.28- \\
1.78)^{\mathrm{a}} \\
\end{array}$ & $\begin{array}{l}1.37(1.28- \\
1.46)^{\mathrm{a}}\end{array}$ \\
\hline $\begin{array}{l}\text { Blood loss } \\
>1000 \mathrm{ml}\end{array}$ & $\begin{array}{l}1.55 \\
(0.74- \\
3.24)\end{array}$ & $\begin{array}{l}1.38 \\
(0.79- \\
2.41)\end{array}$ & $\begin{array}{l}3.11(1.90- \\
5.09)\end{array}$ & $\begin{array}{l}2.70 \\
(2.21- \\
3.30)\end{array}$ & $\begin{array}{l}3.24 \\
(2.74- \\
3.85)\end{array}$ & $\begin{array}{l}2.45(2.29- \\
2.63)\end{array}$ \\
\hline $\begin{array}{l}\text { Manual } \\
\text { placental } \\
\text { removal }\end{array}$ & $\begin{array}{l}2.04 \\
(0.49- \\
8.60) \\
\end{array}$ & $\begin{array}{l}0.54 \\
(0.13- \\
2.21) \\
\end{array}$ & $\begin{array}{l}3.28(1.56- \\
6.89)\end{array}$ & $\begin{array}{l}2.06 \\
(1.63- \\
2.61) \\
\end{array}$ & $\begin{array}{l}1.80 \\
(1.40- \\
2.33) \\
\end{array}$ & $\begin{array}{l}2.72(2.51- \\
2.95)\end{array}$ \\
\hline OASIS & $\begin{array}{l}6.33 \\
(2.42- \\
16.6)\end{array}$ & $\begin{array}{l}0.91 \\
(0.29- \\
2.89)\end{array}$ & $\begin{array}{l}0.40(0.06- \\
2.87)\end{array}$ & $\begin{array}{l}10.7 \\
(9.80- \\
11.9)\end{array}$ & $\begin{array}{l}2.61 \\
(2.15- \\
3.18)\end{array}$ & $\begin{array}{l}1.67(1.52- \\
1.83)\end{array}$ \\
\hline
\end{tabular}

\footnotetext{
${ }^{a}$ only singleton deliveries
}

There were in total 22627 diagnoses of WI, endometritis, UTI and breast abscess in the whole population in paper II. That gives a prevalence of $2.8 \%$, compared to $7.5 \%$ in paper I. 


\section{Paper III}

All singleton deliveries that were recorded in the MBR during the years 2005 to 2012 were included in this study. There were 22095 diagnoses of WI, endometritis and breast abscess among the 841780 deliveries in the study. Almost 23\% of the women were overweight, 7.8\% had BMI 20-34.9 and 3.3\% were morbidly obese. The risk of postpartum infection increased the older the women, decreased with higher parity and was higher for women who smoked 10 or more cigarettes in early pregnancy. There was a dose-dependent increase in risk of postpartum infection with higher BMI. For morbidly obese women the risk of infection was over 50\% higher than for normal weight women (Table $11)$.

Table 11. Maternal BMI and risk of postpartum infection (endometritis, wound infections and breast abscess).

\begin{tabular}{|c|c|c|c|c|c|}
\hline $\begin{array}{l}\text { Body } \\
\text { Mass } \\
\text { Index }\end{array}$ & $\begin{array}{l}\text { Whole } \\
\text { study } \\
\text { population } \\
2005-2012 \\
\mathrm{~N}(\%)\end{array}$ & $\begin{array}{l}\text { No } \\
\text { Infection } \\
\mathrm{N}(\%)\end{array}$ & $\begin{array}{l}\text { Post- } \\
\text { partum } \\
\text { infection } \\
\mathrm{N}(\%)\end{array}$ & $\begin{array}{l}\text { Risk of } \\
\text { postpartum } \\
\text { infection } \\
\text { compared with } \\
\text { whole study } \\
\text { population } \\
\text { aOR }^{\mathrm{a}}(95 \% \mathrm{CI})\end{array}$ & $\begin{array}{l}\text { Risk of } \\
\text { postpartum } \\
\text { infection } \\
\text { compared with } \\
\text { no infection } \\
\text { aOR }^{\mathrm{a}}(95 \% \mathrm{CI})\end{array}$ \\
\hline Unknown & $\begin{array}{l}70509 \\
(8.4)\end{array}$ & $\begin{array}{l}61634 \\
(8.3)\end{array}$ & $\begin{array}{l}1959 \\
(8.9)\end{array}$ & - & - \\
\hline$<18.5$ & $\begin{array}{l}18622 \\
(2.2)\end{array}$ & $\begin{array}{l}16485 \\
(2.2)\end{array}$ & $\begin{array}{l}482 \\
(2.2)\end{array}$ & $1.03(0.94-1.13)$ & $\begin{array}{l}1.03(0.94- \\
1.13)\end{array}$ \\
\hline $18.5-24.9$ & $\begin{array}{l}466606 \\
(55.4)\end{array}$ & $\begin{array}{l}414031 \\
(55.8)\end{array}$ & $\begin{array}{l}11564 \\
(52.3)\end{array}$ & reference & reference \\
\hline $25-29.9$ & $\begin{array}{l}192833 \\
(22.9)\end{array}$ & $\begin{array}{l}169244 \\
(22.8)\end{array}$ & $\begin{array}{l}5197 \\
(23.5)\end{array}$ & $\begin{array}{l}1.13(1.09- \\
.1 .16)\end{array}$ & $\begin{array}{l}1.14(1.10- \\
1.17)\end{array}$ \\
\hline $30-34.9$ & $\begin{array}{l}65261 \\
(7.8)\end{array}$ & $\begin{array}{l}56744 \\
(7.6)\end{array}$ & $\begin{array}{l}1915 \\
(8.7)\end{array}$ & $1.25(1.11-1.31)$ & $\begin{array}{l}1.27(1.21- \\
1.33)\end{array}$ \\
\hline$\geq 35$ & $\begin{array}{l}27869 \\
(3.3)\end{array}$ & $\begin{array}{l}23636 \\
(3.2)\end{array}$ & $\begin{array}{l}978 \\
(4.4)\end{array}$ & $1.51(1.41-1.61)$ & $\begin{array}{l}1.56(1.46- \\
1.67)\end{array}$ \\
\hline Total & 841780 & 741774 & 22095 & - & - \\
\hline
\end{tabular}

${ }^{a}$ Adjustments were made for year of birth, maternal age, parity and smoking in early pregnancy.

For WI and endometritis this dose-dependent increase was the same, but for breast abscess this association was the other way around, that is increasing BMI reduced the risk of breast abscess (Table 12). 
Table 12. Number and risk of infections in different maternal Body Mass Index groups.

\begin{tabular}{|l|l|l|l|l|l|l|l|}
\hline $\begin{array}{l}\text { Body } \\
\text { Mass } \\
\text { Index }\end{array}$ & $\begin{array}{l}\text { No in- } \\
\text { fection }\end{array}$ & \multicolumn{2}{l|}{ Endometritis } & \multicolumn{2}{l|}{ Wound infections } & \multicolumn{2}{l|}{ Breast abscess } \\
\hline & $\mathrm{N}$ & $\mathrm{N}$ & $\begin{array}{l}\mathrm{aOR}^{\mathrm{a}} \\
(95 \% \mathrm{CI})\end{array}$ & $\mathrm{N}$ & $\begin{array}{l}\text { aOR } \\
(95 \% \mathrm{CI})\end{array}$ & $\mathrm{N}$ & $\begin{array}{l}\mathrm{aOR}^{\mathrm{a}} \\
(95 \% \mathrm{CI})\end{array}$ \\
\hline$<18.5$ & 16485 & 278 & $\begin{array}{l}1.03(0.92- \\
1.17)\end{array}$ & 81 & $\begin{array}{l}1.18(0.95- \\
1.48)\end{array}$ & 130 & $\begin{array}{l}0.94(0.79- \\
1.12)\end{array}$ \\
\hline $18.5-24.9$ & 414031 & 6468 & $\begin{array}{l}\text { reference } \\
\text { reference }\end{array}$ & 1758 & 3556 & reference \\
\hline $25-29.9$ & 169244 & 3052 & $\begin{array}{l}1.17(1.12- \\
1.22)\end{array}$ & 978 & $\begin{array}{l}1.42(1.31- \\
1.54)\end{array}$ & 1280 & $\begin{array}{l}0.94(0.88- \\
1.00)\end{array}$ \\
\hline $30-34.9$ & 56744 & 1111 & $\begin{array}{l}1.27(1.19- \\
1.35)\end{array}$ & 526 & $\begin{array}{l}2.35(2.13- \\
2.59)\end{array}$ & 328 & $\begin{array}{l}0.75(0.67- \\
0.84)\end{array}$ \\
\hline$\geq 35$ & 23636 & 516 & $\begin{array}{l}1.42(1.30- \\
1.56)\end{array}$ & 398 & $\begin{array}{l}4.19(3.77- \\
4.66)\end{array}$ & 83 & $\begin{array}{l}0.47(0.38- \\
0.58)\end{array}$ \\
\hline Unknown & 61634 & 1134 & & 382 & & 482 & \\
\hline
\end{tabular}

${ }^{a}$ Adjustments were made for year of birth, maternal age, parity and smoking in early pregnancy

After normal, vaginal delivery high BMI was a risk factor for endometritis, whereas this effect was not seen after instrumental, vaginal delivery or after CS. aORs with $95 \%$ CIs for endometritis in women with BMI $\geq 35$ after normal, vaginal delivery, instrumental, vaginal delivery and CS were, respectively: 1.45 (1.29-1.63), 1.14 (0.77-1.69) and $1.12(0.91-1.31)$.

After CS the risk of WI showed a dramatic increase with higher BMI regardless of the type of CS, whereas no difference was seen after normal vaginal delivery or after instrumental vaginal delivery (Figure 15). 
Figure 15. aORs for wound infections after normal vaginal delivery, instrumental vaginal delivery and after cesarean section in different BMI-groups
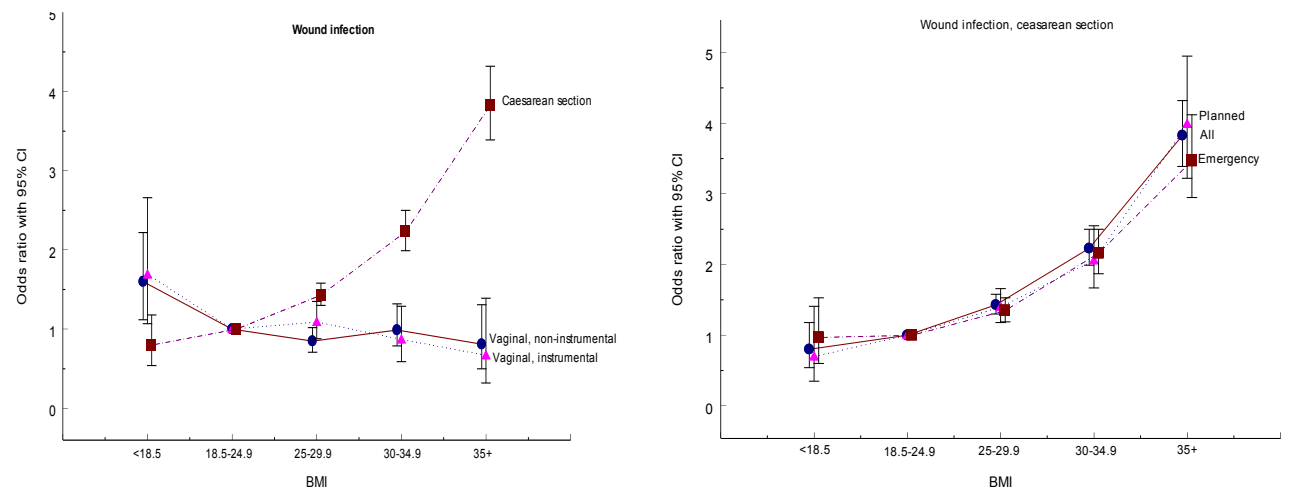

The risk of breast abscess decreased with higher BMI after normal vaginal delivery and after CS, but there was no difference between BMI groups after instrumental vaginal delivery (Figure 16).

Figure 16. aORs for breast abscess after different modes of delivery in different BMI-groups

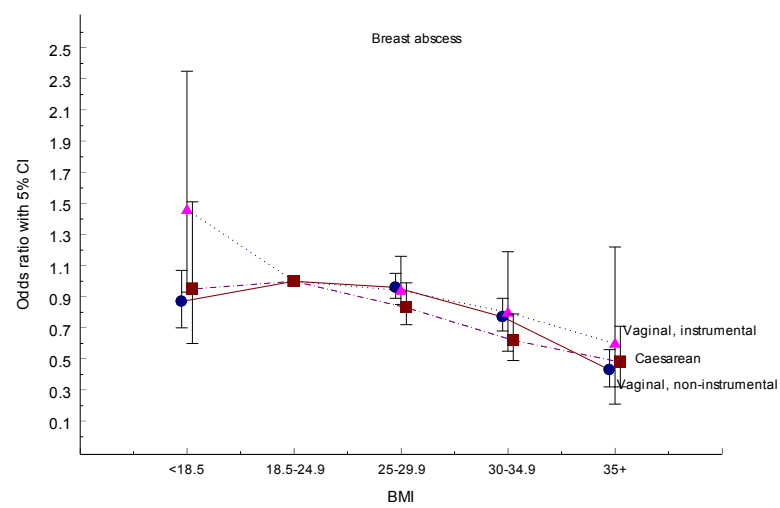

The effect of BMI on risk of postpartum infections was also estimated for preterm, post-term, labor induction, episiotomy, blood loss $>1000 \mathrm{ml}$, anemia, manual placental removal and obstetric anal sphincter injuries. Results for endometritis are presented in Table 13. 
Table 13. Gestational age at delivery, obstetric interventions and postpartum complications and association with endometritis in different BMI groups

\begin{tabular}{|c|c|c|c|c|c|}
\hline BMI & $<18.5$ & $18.5-24.9$ & $25-29-9$ & $30-34.9$ & $\geq 35$ \\
\hline & $\begin{array}{c}\mathrm{N}, \mathrm{OR} \\
(95 \% \mathrm{CI})\end{array}$ & $\begin{array}{c}\mathrm{N}, \mathrm{OR} \\
(95 \% \mathrm{CI})\end{array}$ & $\begin{array}{c}\mathrm{N}, \mathrm{OR} \\
(95 \% \mathrm{CI})\end{array}$ & $\begin{array}{c}\mathrm{N}, \mathrm{OR} \\
(95 \% \mathrm{CI})\end{array}$ & $\begin{array}{c}\mathrm{N}, \mathrm{OR} \\
(95 \% \mathrm{CI})\end{array}$ \\
\hline Diabetes & $\begin{array}{c}0 \\
0.00(0- \\
2.18) \#\end{array}$ & $\begin{array}{c}73 \\
1.30(1.03- \\
1.62)\end{array}$ & $\begin{array}{c}72 \\
1.22(0.96- \\
1.54)\end{array}$ & $\begin{array}{c}37 \\
0.87(0.63- \\
1.22)\end{array}$ & $\begin{array}{c}43 \\
1.36(0.99- \\
1.88)\end{array}$ \\
\hline $\begin{array}{l}<37 \\
\text { weeks* }\end{array}$ & $\begin{array}{c}26 \\
1.37(0.88- \\
2.13)\end{array}$ & $\begin{array}{c}433 \\
1.42(1.29- \\
1.57)\end{array}$ & $\begin{array}{c}214 \\
1.38(1.20- \\
1.59)\end{array}$ & $\begin{array}{c}74 \\
1.15(0.90- \\
1.46)\end{array}$ & $\begin{array}{c}61 \\
1.90(1.44- \\
2.52)\end{array}$ \\
\hline $\begin{array}{l}>41 \\
\text { weeks* }\end{array}$ & $\begin{array}{c}26 \\
2.69(1.78- \\
4.04)\end{array}$ & $\begin{array}{c}511 \\
1.33(1.21- \\
1.46)\end{array}$ & $\begin{array}{c}272 \\
1.23(1.21- \\
1.47)\end{array}$ & $\begin{array}{c}93 \\
1.03(0.84- \\
1.28)\end{array}$ & $\begin{array}{c}56 \\
1.29(0.96- \\
1.73)\end{array}$ \\
\hline $\begin{array}{l}>42 \\
\text { weeks* }\end{array}$ & $\begin{array}{c}0 \\
0.00(0- \\
14.8) \#\end{array}$ & $\begin{array}{c}12 \\
0.97(0.55- \\
1.72)\end{array}$ & $\begin{array}{c}6 \\
0.73(0.27- \\
1.59) \#\end{array}$ & $\begin{array}{c}2 \\
0.49(0.05- \\
1.75) \#\end{array}$ & $\begin{array}{c}1 \\
0.40(0.01- \\
2.23) \#\end{array}$ \\
\hline $\begin{array}{l}\text { Labor } \\
\text { Induction }\end{array}$ & $\begin{array}{c}46 \\
2.18(1.58- \\
3.01)\end{array}$ & $\begin{array}{c}1000 \\
1.52(1.42- \\
1.62)\end{array}$ & $\begin{array}{c}600 \\
1.44(1.32- \\
1.58)\end{array}$ & $\begin{array}{c}257 \\
1.32(1.14- \\
1.52)\end{array}$ & $\begin{array}{c}135 \\
1.21(0.99- \\
1.48)\end{array}$ \\
\hline Episiotomy & $\begin{array}{c}1 \\
0.55(0.08- \\
3.90) \#\end{array}$ & $\begin{array}{c}29 \\
0.82(0.56- \\
1.18)\end{array}$ & $\begin{array}{c}23 \\
1.73(1.14- \\
2.61)\end{array}$ & $\begin{array}{c}2 \\
0.46(0.06- \\
1.68) \#\end{array}$ & $\begin{array}{c}1 \\
0.83(0.02- \\
4.60) \#\end{array}$ \\
\hline $\begin{array}{l}\text { Blood loss } \\
>1000 \mathrm{ml}\end{array}$ & $\begin{array}{c}23 \\
2.62(1.78- \\
3.74)\end{array}$ & $\begin{array}{c}669 \\
2.22(2.05- \\
2.21)\end{array}$ & $\begin{array}{c}299 \\
2.03(1.80- \\
2.29)\end{array}$ & $\begin{array}{c}90 \\
1.64(1.32- \\
2.04)\end{array}$ & $\begin{array}{c}40 \\
1.60(1.14- \\
2.23)\end{array}$ \\
\hline Anemia & $\begin{array}{c}49 \\
3.29(2.42- \\
4.48)\end{array}$ & $\begin{array}{c}957 \\
3.10(2.90- \\
3.31)\end{array}$ & $\begin{array}{c}482 \\
3.10 \\
(2 . .81- \\
3.41)\end{array}$ & $\begin{array}{c}175 \\
2.80(2.38- \\
3.29)\end{array}$ & $\begin{array}{c}91 \\
3.35(2.67- \\
4.21)\end{array}$ \\
\hline $\begin{array}{l}\text { Manual } \\
\text { placental } \\
\text { removal }\end{array}$ & $\begin{array}{c}5 \\
1.34(0.44- \\
3.14) \#\end{array}$ & $\begin{array}{c}230 \\
2.21(1.94- \\
2.52)\end{array}$ & $\begin{array}{c}102 \\
2.12(1.74- \\
2.59)\end{array}$ & $\begin{array}{c}40 \\
2.52(1.84- \\
3.46)\end{array}$ & $\begin{array}{c}19 \\
2.63(1.58- \\
4.11) \#\end{array}$ \\
\hline $\begin{array}{l}\text { 3rd-4th } \\
\text { degree } \\
\text { tears }\end{array}$ & $\begin{array}{c}14 \\
1.54(0.84- \\
2.59) \#\end{array}$ & $\begin{array}{c}251 \\
1.30(1.14- \\
1.48)\end{array}$ & $\begin{array}{c}113 \\
1.37(1.13- \\
1.65)\end{array}$ & $\begin{array}{c}25 \\
0.98(0.65- \\
1.46)\end{array}$ & $\begin{array}{c}14 \\
1.43(0.78- \\
2.40) \#\end{array}$ \\
\hline
\end{tabular}

\#Relative risk as observed over expected numbers with exact 95\% Poisson confidence interval.

*Compared with weeks 37-40 


\section{Paper VI}

In this cohort of 1397 women included at the antenatal clinic, 58\% had vitamin D levels below $50 \mathrm{nmol} / \mathrm{L}$ and $12 \%$ had levels below $25 \mathrm{nmol} / \mathrm{L}$ (Figure 17). A total of 119 ICD-10 codes suggestive of infection were found (Figure 18). No association was found between vitamin D deficiency and overall postpartum infectious morbidity nor was any association with obstetric infections (UTI, endometritis and breast abscess) found. In this material smoking in early pregnancy, CS and being non-primiparous were risk factors for postpartum infections. No diagnoses of WI were present in any of the records.

Figure 17. Distribution of serum 25OHD concentrations in pregnant women at the time of delivery.

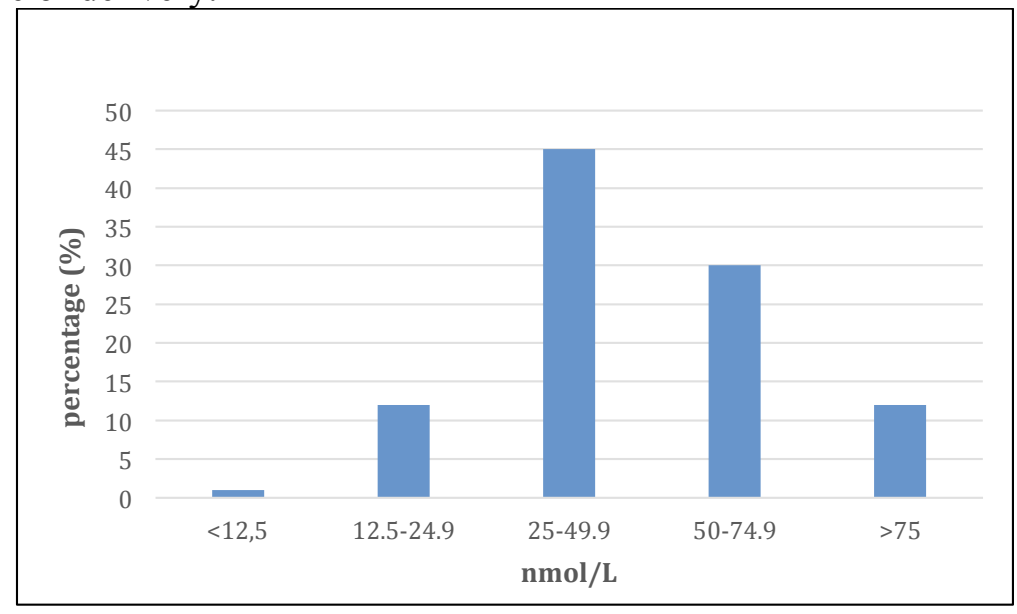

Figure 18. The distribution of infections, in absolute numbers, from delivery to eight weeks postpartum.

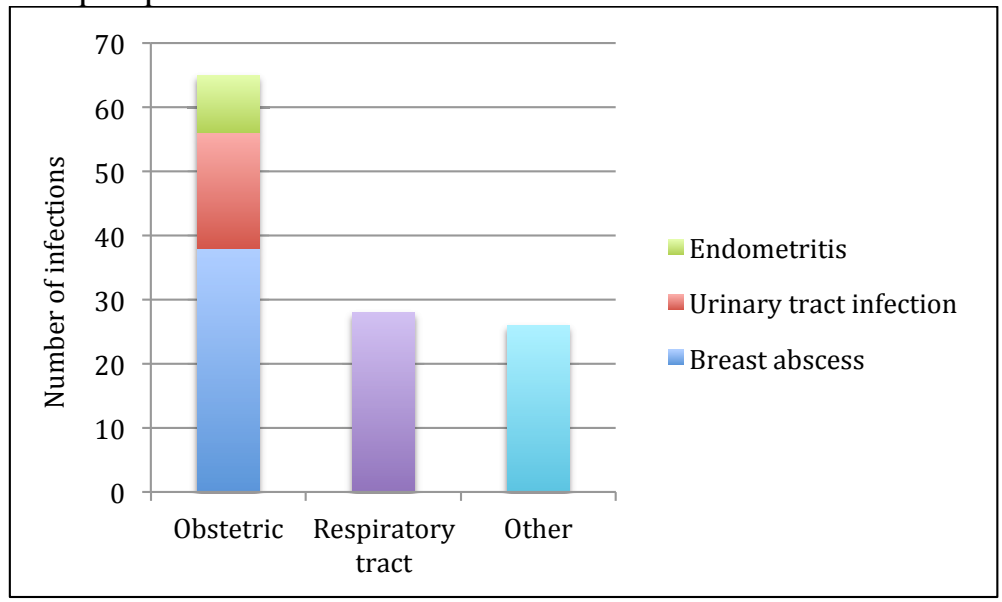


A majority of women had vitamin D deficiency. Table 14 shows the results for vitamin $\mathrm{D}$ status among pregnant women in Scandinavia.

Table 14. Comparison of mean serum 25OHD concentrations and proportion of vitamin D deficiency in pregnant women in Scandinavia in the first and third trimester.

\begin{tabular}{|l|l|l|l|l|l|l|}
\hline & \multicolumn{3}{|l|}{ First trimester } & \multicolumn{3}{l|}{ Third trimester } \\
\hline Study & $\mathrm{N}$ & $\begin{array}{l}\text { Mean } \\
\text { nmol/L } \\
(\mathrm{SD})\end{array}$ & $\begin{array}{l}<50 \mathrm{nmol} / \mathrm{L} \\
(\%)\end{array}$ & $\mathrm{N}$ & $\begin{array}{l}\text { Mean } \\
\text { nmol/ } / \\
\mathrm{L} \\
(\mathrm{SD})\end{array}$ & $\begin{array}{l}<50 \mathrm{nmol} / \mathrm{L} \\
(\%)\end{array}$ \\
\hline $\begin{array}{l}\text { Axelsson et al. 2019 } \\
\text { Sweden }\end{array}$ & & & & 1397 & $\begin{array}{l}45 \\
(22)\end{array}$ & 58 \\
\hline $\begin{array}{l}\text { Bärebring et al. 2016 } \\
\text { Sweden }\end{array}$ & 1985 & $65(25)$ & 25 & 1836 & $\begin{array}{l}75 \\
(34)\end{array}$ & \\
\hline $\begin{array}{l}\text { Eggemoen et al. 2016 } \\
\text { Norway }\end{array}$ & 748 & $50(27)$ & & 748 & $\begin{array}{l}59 \\
(29)\end{array}$ & \\
\hline $\begin{array}{l}\text { Lundqvist et al. 2016 } \\
\text { Sweden }\end{array}$ & 183 & $55(18)$ & 38 & 174 & $\begin{array}{l}65 \\
(27)\end{array}$ & 33 \\
\hline $\begin{array}{l}\text { Bondo Petersen et al. } \\
\text { 2014 Denmark }\end{array}$ & & & & 850 & $\begin{array}{l}76^{\mathrm{a}} \\
25\end{array}$ \\
\hline
\end{tabular}

${ }^{\mathrm{a}}$ median

The proportion of women with vitamin D deficiency varied according to the month of sampling. The lowest proportions were found during the summer months (Figure 19).

Figure 19. Proportion of women with vitamin D deficiency (serum $25 \mathrm{OHD} \leq 50$ $\mathrm{nmol} / \mathrm{L}$ according to month of sampling.

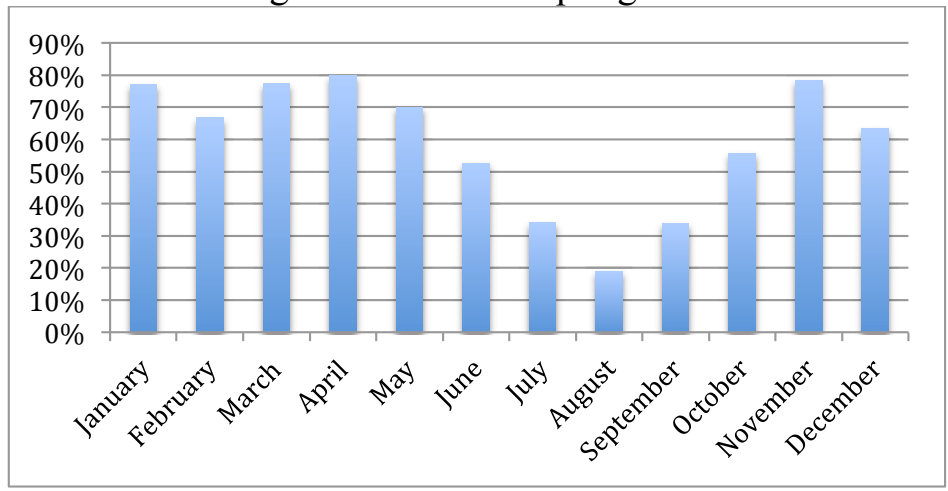




\section{DISCUSSION}

\section{Discussion of the findings}

\section{Prevalence of postpartum infections}

In paper I the results showed a total prevalence of antibiotic treated postpartum infections of $7.5 \%$. As a matter of fact, over $10 \%$ of delivered women reported an infection, but antibiotic treated infection was considered as a more reliable measure for infection since this provides some kind of evidence that a physician has actually diagnosed an infection.

The prevalence of postpartum infections was about half the prevalence found in a Danish study with similar design (38). In the Danish material the prevalences of UTI and endometritis were similar to those in Paper I, while the prevalences of mastitis and WI were three and two times higher, respectively, in Denmark. The proportion of antibiotic-treated infections in the Danish study was the same as in the present study. Since the Danish study partly focused on the association with breast-feeding, that could possibly explain some of the difference. The questionnaires in the Danish study were distributed to the women four weeks postpartum, which could possibly explain some, but probably not all, of the difference in prevalence.

\section{Putative risk factors for postpartum infections}

CS has in several previous studies been shown to be a major risk factor for postpartum infections. This thesis confirmed these results, and the analyses were made on large populations. The result that the risk of WI after emergency CS is about $50 \%$ higher than after elective CS is also in concordance with previous research. One Danish study reported an adjusted OR of 1.68 after CS, compared to vaginal delivery (8). That was just over half of the aOR in the present study. Several methodological differences could possibly explain that difference. The reference population in the Danish study consisted of all vaginal deliveries, whereas the present study used normal, vaginal delivery. Furthermore the Danish study used prescribed "UTI-specific" antibiotics for identification of UTI. That would probably include more patients with mild UTI than in this study, where an unknown proportion of probably milder UTI could have been treated in primary healthcare and would thus not have been identifiable in health care registers.

Maternal characteristics that have been reported as risk factors in smaller studies were also found to be associated with infections in this thesis. Obesity is of great interest with its current epidemic spread in the world. Several studies have 
reported that obese women are at greater risk of contracting infections after delivery. Magann et al. defined BMI thresholds for when the risk of various delivery complications increased (70). The study was relatively small, but the thresholds for WI, UTI and endometritis reported were $\geq 30, \geq 35$ and $\geq 40$, respectively. In the present study, all women with overweight and obesity had an increased risk of all three infections. The highest aOR was for WI, followed by UTI and endometritis, with the same order for every BMI group over normal weight. Sebire et al. reported, similarly to this study, a dose-dependent increase in risk of several infections with higher BMI among women in Great Britain (12). Wloch et al. also reported an increased risk of post-cesarean WI with higher BMI and similar aORs as in the present study (71). Together these studies include over one million women and make it probable that these results are valid for an even larger population.

Ely et al. reported that anemia and manual placental removal were risk factors for postpartum endometritis after vaginal delivery, both with aORs of 2.9 (72). The aORs differ just slightly from the ones in the present study. Chaim et al. also found that postpartum anemia was a risk factor for endometritis with an aOR of 3.84 after vaginal delivery and 1.77 after CS (31). These results have thus also been confirmed in the present study.

For WI after vaginal delivery, being underweight was a risk factor, whereas overweight and obese women had a non-significant lower risk than normal weight women. Breast abscess was significantly more common among underweight women, with lower aORs the higher the BMI. In this thesis, OASIS was found to be a strong risk factor for WI after vaginal delivery with an aOR 10.7 (95\% CI 9.80-11.9). OASIS have previously been reported to be less common among obese women $(73,74)$. Together this could explain the higher aORs for underweight women regarding WI. The fact that obese women breastfeed to a lower extent than normal weight women is probably at least part of the reason for the decreased risk of breast abscess among these women (75, 76).

\section{Vitamin D deficiency}

In paper IV, no association between vitamin D deficiency and postpartum infections was found. The relation between vitamin D deficiency at the time of delivery and postpartum infections has, to our knowledge, not been studied before. Most previous epidemiological studies on the role of vitamin D in infections have studied individual pathogens. In this study, the total infectious morbidity was studied. The mechanisms by which vitamin $\mathrm{D}$ acts in the immune system are complex and it is probable that it is more important for the defense against certain pathogens than others (59). WI, endometritis, UTI and breast 
infections are caused by a variety of different bacteria and in the recently delivered woman several different risk factors for infections are present. Nevertheless, the control group consisted of women with similar background and who had experienced recent deliveries. Mode of delivery, excessive bleeding as well as other known risk factors were adjusted for in the statistical calculations.

The prevalence of vitamin D deficiency was unexpectedly high. One third of women in the north of Sweden have previously been shown to have vitamin D deficiency (63). The inclusion of women in that study took place during the same years as in the present study and during every season of the year, which was also the case with this study. These similarities probably exclude differences in vitamin D supplementation guidelines and major differences in seasonal sun exposure between the two populations. Similar seasonal variations were also found. Furthermore, one would expect women in the south of Sweden to be exposed to at least the same amount of UV radiation from the sun as women in northern Sweden.

Pregnant women of North European origin have in previous studies been reported to have a low risk of vitamin D deficiency in the first trimester $(13 \%)$ (66). With this in mind the prevalence of vitamin D deficiency in this study population (58\%) can be considered as very high, which raise questions about correct cut-off values for pregnant women.

\section{Methodological considerations}

\section{Study design}

Papers I-III in this thesis are observational studies. The data in paper I are both self-reported and collected from medical records. Papers II and III include data exclusively from medical registers, and paper IV is a translational study with data from medical records combined with laboratory analyses.

All data from records and registers were prospectively collected and this type of study design permits a use of large amount of information without the disadvantages of long study time. Large quantities of data give the possibility to study outcomes in groups with relatively unusual exposures, for example morbid obesity. The internal validity in observational studies is affected by systematic and random errors. The risk of random errors decreases with increasing size of the study population, but the risk of systematic errors (bias) is not reduced. When conducting observational studies, one has to consider three types of bias: confounding bias, information bias and selection bias (77).

When the causes of both exposure and outcome are not adjusted for, a confounding bias occurs. These factors are called confounders. Since paper I is a 
prevalence study, the risk of confounding bias was not applicable. In papers II and III, adjustments were made for well-known confounding factors such as age, parity, smoking in early pregnancy and BMI. Year of delivery was also adjusted for to rule out the possibility that changes in national guidelines during the study period would affect the risk estimates. In paper IV, possible confounders were analyzed as crude odds ratios with regression analyses. Parity, smoking in early pregnancy and mode of delivery were adjusted for in the final analyses. Inaccurately measured or recorded data presents a risk for information bias. Data on self-reported BMI and smoking have previously been validated (78-80), as have the registers used in this thesis $(23,24,81)$. The validated Swedish medical health registers consist of data from the medical records equal to those used in papers I and IV. This might indicate that the quality of the data in papers I and IV is on a similar level as the registers. Self-reported infections represent a possible source of information bias in paper I. The validation of diagnoses in the study is small and was only performed for one infection diagnosis in one hospital. In paper IV, an accredited laboratory conducted the vitamin D analyses.

The risk of selection bias occurs when there are other differences than the outcome between the studied groups, and the differences can be assumed to affect the outcome. In paper II the study population was restricted to only term deliveries in order to eliminate the possibility that premature delivery caused by chorioamnionitis would affect the outcome. In paper IV no exclusions were made, but calculations were made separately for different modes of delivery. The external validity measures the possibility of extrapolating the results from a study to a larger population than the one studied. In paper I a comparison was made between responders and non-responders with small differences in maternal characteristics. The difference reached statistical significance, but was regarded as not clinically significant. The results are therefore probably generalizable to the entire population in southeast Sweden and possibly to the entire country. Since health care during pregnancy is free in Sweden, almost every woman gives birth in a public hospital and clinical guidelines are similar throughout the country. Papers I and III include the whole Swedish population so the results could be considered as valid for the entire population, and possibly also for similar populations in other countries. Different routines and guidelines for specific interventions and complications in other settings reduce the validity in those populations. The population in paper IV consisted of women in Linköping, a Swedish town with a high average level of education (over $37 \%$ of citizens have $\geq 3$ years of university studies). Good knowledge and understanding of the Swedish language was required for inclusion in the Pregnancy Biobank. There are no data on socioeconomic status regarding the study population, but based on the inclusion process to the Biobank, the assumption could be made that a majority of women in the study are of Swedish origin. Furthermore, there was a relatively high rate of normal, vaginal delivery in the study group $(88 \%)$, 
suggesting a high proportion of non-complicated pregnancies. With this in mind, the external validity of the results in paper IV may be low in a population with different maternal characteristics.

\section{Study populations}

In paper I, the response rate was just over $60 \%$. There was a small but significant difference between responders and non-responders regarding age, parity and BMI. The clinical significance of these differences was considered small, and given that the different delivery wards in the southeast region in Sweden have close collaboration and mutual or very similar routines and guidelines, the results can probably be extrapolated to the entire population. The populations in papers II and III consisted of all women in Sweden over eight years. There are some missing data in the material, which is expected with the registers used. However, the distribution of errors can be assumed to be random, and not dependent on the individual women or care providers. Given the size of the populations, risk estimates are thus probably not affected.

\section{Surveillance of postpartum infections}

Questionnaires have been questioned as an instrument for assessing infection prevalence surveillance. They have been reported to have a low sensitivity (20). However, they do not rely on correct coding of diagnoses from the health care provider, and women may get medical care from primary care providers that in Sweden do not report to registers. Many infections are diagnosed and treated without any bacterial culture taken, and cultures of postpartum infections have a high risk of contamination. The PDR provides information about filled prescriptions of antibiotics but does not contain information about what type of infection the antibiotics were intended to treat.

When the records of a small group of women who reported endometritis $(n=18)$ were scrutinized, there was evidence that every one of these women had been prescribed antibiotics for infection. The diagnosis was correctly reported in $89 \%$ of cases. However, only $31 \%$ had an ICD-10 code suggestive of infection. The infections were self-reported and the accuracy of this methodology can be difficult to determine. It is interesting that the subgroup analysis on women at Ryhov County hospital, although small, showed that less than one third of cases of endometritis actually had a correct diagnosis code.

Paper II was not a prevalence study, but in only $2.8 \%$ of the deliveries in this study was a diagnosis of the infections evaluated in paper I found. That is, the prevalence of postpartum infections in the register-based material in paper II was $37 \%$ of that in the questionnaire-based material in paper I. 
Danish researchers have previously described this superiority in questionnaires, concerning the ability to identify postpartum infections. In a questionnaire-based study from 2012 , only $66 \%$ of reported infections were confirmed by a doctor (38). The content validity of the questionnaire in paper I (appendix) was assessed before use. This, together with the comparison of answers and records at the Department of Obstetrics and Gynecology, Ryhov County Hospital in Jönköping, suggest a reasonably high validity of the questionnaire.

This thesis does not actually study infections. In paper I the outcome was selfreported infection. The validation of the answers suggests a certain sensitivity, but the true prevalence of actual infections may be smaller, or higher, than the results imply. In papers II and III infections were defined as the presence of ICD-10 codes suggestive of infection. The strength of using registers compared to questionnaires is that doctors make the diagnoses and the populations consist of large numbers of women. The ICD-10 codes chosen to define certain infections were the most commonly used codes. There is a large difference between the different infection diagnoses regarding the source of the ICD-10 code. Only a minority of diagnoses of WI and endometritis were found in the MBR, while as many as $84 \%$ of UTI diagnoses were registered in the MBR. This strengthens the results that the peak occurrence of UTI is earlier than for WI and endometritis. If data on the actual date of diagnosis during the referral for delivery had been available, it is possible that the peak occurrence for UTI would have been shown to be even sooner after delivery than the results in this study suggested.

The ICD-10 codes in paper IV were extracted directly from medical records. Codes from obstetric records and specialist in- and out-patient care would have been registered in the MBR and the PR, but diagnoses from primary care providers would have been lost since they do not report to the PR.

\section{Statistics}

The Mantel-Haenszel technique was used instead of logistic regression in papers II and III. The drawback with Mantel-Haenszel is that if one does not have enough control cases in a stratum, the information in that stratum is lost. The risk for this is small when the control population is large, as was the case in these papers (all women were without signs of infection). When the control population is small, a logistic regression is more efficient because in the case of missing control data the expected number is estimated from regressions. The drawback is the need for adequate regressions, which are not necessarily linear. Missing data in the Mantel-Haenszel analysis are treated as separate strata, which is why information is not lost (67). The Mantel-Haenszel analyses were run using programs, written ad hoc. 


\section{Clinical implications}

The most important contribution of this thesis is that it casts light on the phenomenon that virtually anything that is not considered "normal" also acts as a risk factor for postpartum infections. Any intervention made increases the risk of infectious morbidity Anemia emerges as the strongest risk factor, only preceded by iatrogenic wounds, instrumental vaginal delivery, and OASIS for WI. From an infectious point of view, the results strongly speak against interventions that are avoidable. Efforts should also be made to reduce the proportion of women who lose excessive amounts of blood during delivery, especially those who also undergo some type of intervention. A lower hemoglobin threshold for blood transfusion could possibly be considered for women with postpartum anemia. Furthermore, it is of great importance that society and the medical community act together to reduce the proportion of women who are overweight and obese. Whether routine antibiotic prophylaxis to groups of women other than the ones being treated already (i.e. CS and OASIS) could be beneficial, especially in the light of increasing microbial resistance to antibiotics, need to be investigated in designed randomized control trials. However, combinations of other risk factors may together suggest the advisability of considering prophylactic antibiotics for certain women, or at least of providing a more thorough follow-up after delivery regarding infections. 


\section{CONCLUSIONS}

Based on the studies in this thesis, the following conclusions can be drawn.

- More than one out of ten women in the southeast region of Sweden reported a postpartum infection. $7.5 \%$ of women reported at least one antibiotic-treated postpartum infection.

- Obstetric interventions and complications increased the risk of postpartum infection.

- Peak occurrence after hospital discharge of UTI was six days postpartum and for WI and endometritis the peak occurrence was seven days.

- There was a dose-dependent relationship between an increasing maternal BMI and a higher risk of postpartum infections. BMI was an independent risk factor for postpartum endometritis after normal vaginal delivery and for WI after CS. There was no difference in how BMI affected the association between CS and WI, regardless of whether it was a planned CS or an emergency CS.

- Almost one out of six women had vitamin D deficiency at the time of delivery.

- Vitamin D deficiency among pregnant women at the time of delivery did not increase the risk of postpartum infections. 


\section{FUTURE PERSPECTIVES}

- To evaluate different types of surveillance for postpartum infections, including questionnaires, all available register data and prospective follow-up of delivered women in order to assess the best quality infection surveillance for postpartum infections.

- Double blind randomized control trials, where women with several risk factors for postpartum infections are treated with antibiotic prophylaxis to prevent postpartum infections.

- To study whether a lower hemoglobin threshold for blood transfusion to delivered women with anemia reduces the risk of postpartum infections.

- To correlate breast-feeding patterns to breast abscess among women in different BMI groups.

- To further investigate the unexpectedly high prevalence of vitamin Ddeficiency among pregnant women in Linköping. 


\section{POPULÄRVETENSKAPLIG SAMMANFATTNING}

\section{Bakgrund}

Upp till var femte kvinna som föder barn drabbas av sårinfektion, livmoderinflammation, urinvägsinfektion eller bröstinfektion efter sin förlossning. Dessa infektioner skapar ett betydande lidande för de enskilda kvinnorna, och infektioner efter förlossning orsakar årligen ett stort antal dödsfall i världen. Dessutom innebär detta en stor kostnad för samhället. Ett antal riskfaktorer för infektion efter förlossning har beskrivits, av vilka kejsarsnitt är den mest väl studerade. För att kunna förebygga infektioner efter förlossning behövs ytterligare forskning avseende riskfaktorer. Övervikt och fetma ökar snabbt i nästan alla länder i världen. Gravida kvinnor är inget undantag från detta, och högt BMI har visats vara associerat till ökad risk för flera komplikationer under graviditet och förlossning samt under barnsängstiden. Exempel på sådana komplikationer är graviditetsdiabetes, havandeskapsförgiftning och kejsarsnitt. Att fetma är en riskfaktor för sårinfektion efter kejsarsnitt är känt, men hur graden av övervikt och fetma påverkar risken för infektioner efter olika förlossningssätt är inte studerat. D-vitamin är viktigt för skelettet, men brist på D-vitamin har även visats vara associerat med en ökad risk för olika typer av infektioner. Det saknas kunskap om huruvida D-vitaminbrist under graviditeten leder till ökad risk för infektioner efter förlossning.

\section{Syfte med avhandlingen}

- Att undersöka förekomsten av sårinfektion, livmoderinflammation, urinvägsinfektion och bröstinfektion efter förlossning hos kvinnor i sydöstra sjukvårdsregionen under ett år. (studie 1)

- Att utvärdera riskfaktorer för ovan nämnda infektioner. (studie 2)

- Att beräkna den genomsnittliga tiden från förlossning till debut av infektion. (studie 2)

- Att undersöka hur risken för infektion varierar utifrån kvinnans BMI efter olika förlossningssätt. (studie 3)

- Att undersöka förekomsten av D-vitaminbrist hos gravida kvinnor vid tiden för förlossning. (studie 4)

- Att undersöka om D-vitaminbrist i slutet av graviditeten ger en ökad risk för infektioner efter förlossningen. (studie 4) 


\section{Material och metod}

I studie 1 fick alla 11124 kvinnor som födde barn i sydöstra sjukvårdsregionen under ett år en enkät. De ombads ange om de haft någon infektion i sår, livmoder, urinvägar eller bröst under de första åtta veckorna efter sin förlossning, samt om de fått antibiotika för sin infektion. De som besvarade enkäten jämfördes med de som inte svarade avseende bakgrundsdata och förlossningssätt för att värdera om resultaten kan vara generaliserbara för hela populationen.

I studie 2 och 3 användes data från Medicinska Födelseregistret, Patientregistret och Läkemedelsregistret. Alla förlossningar under åtta år (2005-2012) identifierades och data från de olika registren kopplades samman. I studie 2 användes endast fullgångna graviditeter (795 072 st.) och risken för sårinfektion, livmoderinflammation och urinvägsinfektion efter förlossning utifrån kvinnornas bakgrundsdata, förlossningssätt och komplikationer under och efter förlossning beräknades. För dessa beräkningar jämfördes kvinnor som hade en diagnoskod som talade för att de haft någon av de studerade infektionerna inom åtta veckor efter förlossning med friska kvinnor. Friska kvinnor definierades som de som varken hade någon infektionsdiagnos alls eller något expedierat recept på antibiotika under åtta veckor efter sin förlossning. I studie 3 låg samtliga 841780 förlossningar till grund för analyserna. Kvinnorna delades upp i fem BMI-grupper och risken för sårinfektion, livmoderinflammation och bröstböld efter olika förlossningssätt undersöktes och jämfördes mellan BMIgrupperna.

I studie 4 användes 1397 blodprover från graviditetsbiobanken i Linköping. Biobanken innehåller prover som lämnats av kvinnor under sin graviditet, avsedda för framtida forskning. Proverna som användes i denna studie var tagna i samband med förlossning. Proverna analyserades avseende D-vitaminhalt och andelen kvinnor med D-vitaminbrist beräknades. Data avseende kvinnorna, samt diagnoskoder, hämtades från kvinnornas journaler. Kvinnor med D-vitaminbrist jämfördes med kvinnor med normala D-vitaminnivåer avseende förekomst av någon infektionsdiagnos.

\section{Resultat}

Enkäten i studie 1 besvarades av drygt $60 \%$ av de tillfrågade. Mer än en av tio kvinnor angav att de haft infektion efter sin förlossning, medan $7.5 \%$ svarade att de haft en antibiotikabehandlad infektion.

I studie 2 visade resultaten att kejsarsnitt var den största riskfaktorn för sårinfektion efter förlossning, med 17 gånger ökad risk jämfört med normal vaginal förlossning. Stor bristning i underlivet och klipp i mellangården gav båda tio gånger ökad risk för sårinfektion. Blodbrist efter förlossningen var den 
största riskfaktorn för både livmoderinflammation och urinvägsinfektion med tre respektive fyra gånger ökad risk. För livmoderinflammation kom manuellt uthämtande av moderkakan och akut kejsarsnitt på andra plats, båda med 2.7 gånger ökad risk. Risken för urinvägsinfektion ökade ca 3.5 gånger efter förlossning med sugklocka/tång samt efter akut kejsarsnitt. Den genomsnittliga tiden från förlossning till debut av infektion för kvinnor efter utskrivning från förlossningstillfället var sex dagar för urinvägsinfektion och sju dagar för livmoderinflammation och sårinfektion.

I studie 3 visade sig högt BMI vara en unik riskfaktor för infektion efter förlossning och risken ökade med högre BMI. För de enskilda infektionerna ökade risken för livmoderinflammation med ökande BMI efter normal vaginal förlossning. Risken för sårinfektion efter kejsarsnitt ökade kraftigt ju högre BMI kvinnorna hade, och detta förhållande var det samma oavsett om kejsarsnittet var planerat eller akut. Risken för bröstböld minskade ju högre BMI kvinnorna hade.

I den studie 4 visade sig D-vitaminbrist vid tiden för förlossning vara så vanligt förekommande som hos $58 \%$ av kvinnorna. Något samband mellan Dvitaminbrist och infektion efter förlossning kunde inte hittas.

\section{Diskussion}

Denna avhandling presenterade för första gången data på hur vanligt förekommande infektioner var efter förlossning i Sverige. Med hjälp av stora studiematerial gav den information om olika riskfaktorer för infektioner efter förlossning och den visade tydligt hur ökande grad av övervikt och fetma gav en ökande risk för infektion efter förlossning. Att denna riskökning inte påverkas av vilken typ av kejsarsnitt som utförs har inte tidigare visats. Vidare visade den att en oväntat hög andel kvinnor i Linköping led av D-vitaminbrist i slutet av graviditeten. Att D-vitaminbrist inte var associerat med infektioner efter förlossning har inte heller beskrivits förut. 


\section{ACKNOWLEDGEMENTS}

I would like to thank everyone who in different ways has made this thesis possible. I also want to mention a few people that have meant a lot to me during this process. I am truly grateful to you all.

Professor Marie Blomberg, my main supervisor, lucky, lucky me. Thank you is not enough. You gave me the interest in obstetrics during medical school. You supported me during my early scientific "vomits" and you have never failed in making me believe that you believe in me, neither when I have been too enthusiastic nor when I have hibernated far from you. Your feedback has always focused on the positive (ok, just not once) and the late night chats with you have without exception filled me with energy for my task. I am proud to have been your student.

Professor Jan Brynhildsen, my co-supervisor. For your patience and your nonpatience. For supporting me in my way. You quickly learnt who I am and delivered valuable feedback in proper ways at proper times.

Professor Bengt Källén, Univerity of Lund, for invaluable help with compilation of register data and statistic calculations for papers II and III. For transportation services, the lunches at your home, and the en passant sightseeing in Lund.

Mats $P$ Nilsson, statistician, for endless help and teaching in statistics during study I.

Karin Söderman, for the help with the samples and data from GRABB.

All women participating in GRABB and the staff at antenatal care clinic in Linköping and Motala for recruiting women to GRABB.

The southeast regional obstetric group, for assisting in collection of data for Paper I.

Professor Ann Josefsson, professor Gunilla Sydsjö, associate professor AnnaClara Spetz Holm, Associate professor Ing-Marie Claesson, Dr Caroline Lilliecreutz and dr Kristina Kernell for valuable and helpful comments on the manuscripts and the thesis.

The FOPPers, my research team, for fun, relaxed and intellectual discussions and support. 
Dr Raymond Lenrick, former head of the Department of Obstetrics and Gynecology, Ryhov County Hospital for all the words that made me strong.

Dr Birgitta Gustavsson Borg, former head of the Department of Obstetrics and Gynecology, Ryhov County Hospital for believing in me as a junior researcher.

Dr Johan Skoglund, head of the Department of Obstetrics and Gynecology, Ryhov County Hospital for allowing me to put science before production.

Dr Ann-Marie Berglund, my idol in obstetrics. For showing me the right way.

Dr Pia Tegebäck Bååth, my docscheduler. For your helpful struggle with the schedule when my mind was in science, not in the clinic.

Dr Helene Astrand, my professional kindred spirit. For never-ending emotional support. And for counting me in, even though I was out.

Dr Laila Falknäs, my supervisor as a registrar. For your professionalism and your humor. For supporting me in going my own way.

All my colleagues and friends at the Department of Obstetrics and Gynecology, Ryhov County Hospital for not giving up on me. And for making my work interesting and fun.

Dr Eric Hildebrand, my bro. For giving me the courage to take this journey.

Dr Ola Fridman Bengtsson, my partner in crime. For all the days and all the nights. And for your heart. And for your father Håkan, who set us up with Sam.

Håkan Andersson, my skygod. For showing me heaven. And keeping me there.

Maria Magnusson, my friend. For sharing the experience of disaster. And for holding my hand, climbing to a higher level than before.

Futurum - the academy for healthcare, Region Jönköping County, Sweden, for financial support during my time as a $\mathrm{PhD}$ student.

Janeric Axelsson, my great father. For giving me responsibility. For supporting me in my decisions and in my life, the way I need. And for being not just my father, but also my buddy. 
Inger Axelsson, my late mother. For the perspective of life that makes the days easy. Even the hard ones. For my empathy. For the ability to not listen too much to others. And I know you would have been proud now, wouldn't you?

Jacob Axelsson, my lilbro. Smarter and funnier. And almost as good looking. For tough times and bright times. For giving me the answers, anytime. For being my friend and my role model.

Folke and Malte, my beautiful sons and miracles. My goalkeepers. For hugs and kisses. You are the greatest in my life. I am proud to be your father. Every day.

Evelina Axelsson, my beloved wife and best friend. For the proofreading and the magic hacking in Microsoft Excel. For your patience and support. For our boys. For walking the fields of gold with me. And for keeping the world at bay for me. 


\section{REFERENCES}

1. Hallett $C$. The attempt to understand puerperal fever in the eighteenth and early nineteenth centuries: the influence of inflammation theory. Medical history. 2005;49(1):1-28.

$2 . \quad$ Lane HJ, Blum N, Fee E. Oliver Wendell Holmes (1809-1894) and Ignaz Philipp Semmelweis (1818-1865): preventing the transmission of puerperal fever. American journal of public health. 2010;100(6):1008-9.

3. Gordon A. Classic pages in obstetrics and gynecology. Alexander Gordon. A treatise on the epidemic puerperal fever of Aberdeen. London, G.G. and J. Robinson, 1795. American journal of obstetrics and gynecology. 1974;119(2):263.

4. Dunn PM. Ignac Semmelweis (1818-1865) of Budapest and the prevention of puerperal fever. Archives of disease in childhood Fetal and neonatal edition. 2005;90(4):F345-8.

5. Ronsmans C, Graham WJ. Maternal mortality: who, when, where, and why. Lancet (London, England). 2006;368(9542):1189-200.

6. Maharaj D. Puerperal pyrexia: a review. Part I. Obstetrical \& gynecological survey. 2007;62(6):393-9.

7. Tharpe N. Postpregnancy genital tract and wound infections. Journal of midwifery \& women's health. 2008;53(3):236-46.

8. $\quad$ Leth RA, Moller JK, Thomsen RW, Uldbjerg N, Norgaard M. Risk of selected postpartum infections after cesarean section compared with vaginal birth: a five-year cohort study of 32,468 women. Acta obstetricia et gynecologica Scandinavica. 2009;88(9):976-83.

9. Burrows LJ, Meyn LA, Weber AM. Maternal morbidity associated with vaginal versus cesarean delivery. Obstetrics and gynecology. 2004;103(5 Pt 1):907-12.

10. Haeri S, Baker AM. Estimating risk factors and causes for postpartum febrile morbidity in teenage mothers. Journal of obstetrics and gynaecology : the journal of the Institute of Obstetrics and Gynaecology. 2013;33(2):149-51.

11. Marchi J, Berg M, Dencker A, Olander EK, Begley C. Risks associated with obesity in pregnancy, for the mother and baby: a systematic review of reviews. Obesity reviews : an official journal of the International Association for the Study of Obesity. 2015;16(8):621-38.

12. Sebire NJ, Jolly M, Harris JP, Wadsworth J, Joffe M, Beard RW, et al. Maternal obesity and pregnancy outcome: a study of 287,213 pregnancies in London.

International journal of obesity and related metabolic disorders : journal of the International Association for the Study of Obesity. 2001;25(8):1175-82.

13. Lang PO, Samaras N, Samaras D, Aspinall R. How important is vitamin D in preventing infections? Osteoporosis international : a journal established as result of cooperation between the European Foundation for Osteoporosis and the National Osteoporosis Foundation of the USA. 2013;24(5):1537-53.

14. Thomason J, Rentsch C, Stenehjem EA, Hidron AI, Rimland D. Association between vitamin D deficiency and methicillin-resistant Staphylococcus aureus infection. Infection. 2015;43(6):715-22.

15. Martineau AR, Jolliffe DA, Hooper RL, Greenberg L, Aloia JF, Bergman P, et al. Vitamin D supplementation to prevent acute respiratory tract infections: systematic review and meta-analysis of individual participant data. BMJ (Clinical research ed). 2017;356:i6583. 
16. Karsnitz DB. Puerperal infections of the genital tract: a clinical review. Journal of midwifery \& women's health. 2013;58(6):632-42.

17. Sands K, Vineyard G, Platt R. Surgical site infections occurring after hospital discharge. The Journal of infectious diseases. 1996;173(4):963-70.

18. Hebert PR, Reed G, Entman SS, Mitchel EF, Jr., Berg C, Griffin MR. Serious maternal morbidity after childbirth: prolonged hospital stays and readmissions. Obstetrics and gynecology. 1999;94(6):942-7.

19. Holbrook KF, Nottebart VF, Hameed SR, Platt R. Automated postdischarge surveillance for postpartum and neonatal nosocomial infections. The American journal of medicine. 1991;91(3b):125s-30s.

20. Yokoe DS, Christiansen CL, Johnson R, Sands KE, Livingston J, Shtatland ES et al. Epidemiology of and surveillance for postpartum infections. Emerging infectious diseases. 2001;7(5):837-41.

21. Liu S, Heaman M, Joseph KS, Liston RM, Huang L, Sauve R, et al. Risk of maternal postpartum readmission associated with mode of delivery. Obstetrics and gynecology. 2005;105(4):836-42.

22. Källen B KK. The Swedish Medical Birth Register - A summary of content and quality. Research Report. Centre For Epidemiology, Swedish National Board of Health and Welfare: 2003 2003-112-3.

23. Ludvigsson JF, Andersson E, Ekbom A, Feychting M, Kim JL, Reuterwall C, et al. External review and validation of the Swedish national inpatient register. BMC public health. 2011;11:450.

24. Wettermark B, Hammar N, Fored CM, Leimanis A, Otterblad Olausson P, Bergman U, et al. The new Swedish Prescribed Drug Register--opportunities for pharmacoepidemiological research and experience from the first six months. Pharmacoepidemiology and drug safety. 2007;16(7):726-35.

25. French L. Prevention and treatment of postpartum endometritis. Current women's health reports. 2003;3(4):274-9.

26. Jacobsson B, Pernevi P, Chidekel L, Jorgen Platz-Christensen J. Bacterial vaginosis in early pregnancy may predispose for preterm birth and postpartum endometritis. Acta obstetricia et gynecologica Scandinavica. 2002;81(11):1006-10. $27 . \quad$ Duff P. Pathophysiology and management of postcesarean endomyometritis. Obstetrics and gynecology. 1986;67(2):269-76.

28. Gibbs RS, O'Dell TN, MacGregor RR, Schwarz RH, Morton H. Puerperal endometritis: a prospective microbiologic study. American journal of obstetrics and gynecology. 1975;121(7):919-25.

$29 . \quad$ Rosene K, Eschenbach DA, Tompkins LS, Kenny GE, Watkins H.

Polymicrobial early postpartum endometritis with facultative and anaerobic bacteria, genital mycoplasmas, and Chlamydia trachomatis: treatment with piperacillin or cefoxitin. The Journal of infectious diseases. 1986;153(6):1028-37.

30. Lewicky-Gaupp C, Leader-Cramer A, Johnson LL, Kenton K, Gossett DR. Wound complications after obstetric anal sphincter injuries. Obstetrics and gynecology. 2015;125(5):1088-93.

31. Chaim W, Bashiri A, Bar-David J, Shoham-Vardi I, Mazor M. Prevalence and clinical significance of postpartum endometritis and wound infection. Infectious diseases in obstetrics and gynecology. 2000;8(2):77-82.

32. Normand MC, Damato EG. Postcesarean infection. Journal of obstetric, gynecologic, and neonatal nursing : JOGNN. 2001;30(6):642-8. 
33. Tuuli MG, Liu L, Longman RE, Odibo AO, Macones GA, Cahill AG. Infectious morbidity is higher after second-stage compared with first-stage cesareans. American journal of obstetrics and gynecology. 2014;211(4):410.e1-6.

34. Maharaj D. Puerperal Pyrexia: a review. Part II. Obstetrical \& gynecological survey. 2007;62(6):400-6.

$35 . \quad$ Kawakita T, Landy HJ. Surgical site infections after cesarean delivery: epidemiology, prevention and treatment. Maternal health, neonatology and perinatology. 2017;3:12.

36. Schneid-Kofman N, Sheiner E, Levy A, Holcberg G. Risk factors for wound infection following cesarean deliveries. International journal of gynaecology and obstetrics: the official organ of the International Federation of Gynaecology and Obstetrics. 2005;90(1):10-5.

37. Barbosa-Cesnik C, Schwartz K, Foxman B. Lactation mastitis. Jama. 2003;289(13):1609-12.

38. Ahnfeldt-Mollerup P, Petersen LK, Kragstrup J, Christensen RD, Sorensen B. Postpartum infections: occurrence, healthcare contacts and association with breastfeeding. Acta obstetricia et gynecologica Scandinavica. 2012;91(12):1440-4. 39. Foxman B, D'Arcy H, Gillespie B, Bobo JK, Schwartz K. Lactation mastitis: occurrence and medical management among 946 breastfeeding women in the United States. American journal of epidemiology. 2002;155(2):103-14.

40. Kinlay JR, O'Connell DL, Kinlay S. Risk factors for mastitis in breastfeeding women: results of a prospective cohort study. Australian and New Zealand journal of public health. 2001;25(2):115-20.

41. Foxman B, Barlow R, D'Arcy H, Gillespie B, Sobel JD. Urinary tract infection: self-reported incidence and associated costs. Annals of epidemiology. 2000;10(8):50915.

42. Butler CC, Hawking MK, Quigley A, McNulty CA. Incidence, severity, help seeking, and management of uncomplicated urinary tract infection: a population-based survey. The British journal of general practice : the journal of the Royal College of General Practitioners. 2015;65(639):e702-7.

43. Claeys KC, Blanco N, Morgan DJ, Leekha S, Sullivan KV. Advances and Challenges in the Diagnosis and Treatment of Urinary Tract Infections: the Need for Diagnostic Stewardship. Current infectious disease reports. 2019;21(4):11.

44. Brown P, Ki M, Foxman B. Acute pyelonephritis among adults: cost of illness and considerations for the economic evaluation of therapy. PharmacoEconomics. 2005;23(11):1123-42.

45. Ronald A. The etiology of urinary tract infection: traditional and emerging pathogens. Disease-a-month : DM. 2003;49(2):71-82.

46. Schmiemann G, Kniehl E, Gebhardt K, Matejczyk MM, Hummers-Pradier E. The diagnosis of urinary tract infection: a systematic review. Deutsches Arzteblatt international. 2010;107(21):361-7.

47. Obesity: preventing and managing the global epidemic. Report of a WHO consultation. World Health Organization technical report series. 2000;894:i-xii, 1-253. 48. Organization WH. Body Mass Index - BMI: WHO; 2019 [Available from: http://www.euro.who.int/en/health-topics/disease-prevention/nutrition/a-healthylifestyle/body-mass-index-bmi.

49. Global Health Observatory Data: WHO; 2019 [Available from:

https://www.who.int/gho/ncd/risk_factors/overweight/en/. 
51. Socialstyrelsen. Förlossningsstatistik, Procent, Riket, Ålder: Alla åldrar, Totalt, 20162016 [Available from:

http://www.socialstyrelsen.se/statistik/statistikdatabas/graviditeterforlossningarochnyfodda.

52. Holick MF. Vitamin D deficiency. The New England journal of medicine. 2007;357(3):266-81.

53. Bikle DD. Vitamin D metabolism, mechanism of action, and clinical applications. Chemistry \& biology. 2014;21(3):319-29.

54. Yamamoto E, Jorgensen TN. Immunological effects of vitamin D and their relations to autoimmunity. Journal of autoimmunity. 2019.

55. Green M. Cod liver oil and tuberculosis. BMJ (Clinical research ed). 2011;343:d7505.

56. Hart PH, Gorman S, Finlay-Jones JJ. Modulation of the immune system by UV radiation: more than just the effects of vitamin D? Nature reviews Immunology. 2011;11(9):584-96.

57. Tan SY, Linskey K. Niels Finsen (1860-1904): Gift of light. Singapore medical journal. 2011;52(11):777-8.

58. Watkins RR, Lemonovich TL, Salata RA. An update on the association of vitamin D deficiency with common infectious diseases. Canadian journal of physiology and pharmacology. 2015;93(5):363-8.

59. Kroner Jde C, Sommer A, Fabri M. Vitamin D every day to keep the infection away? Nutrients. 2015;7(6):4170-88.

60. Hoe E, Nathanielsz J, Toh ZQ, Spry L, Marimla R, Balloch A, et al. AntiInflammatory Effects of Vitamin D on Human Immune Cells in the Context of Bacterial Infection. Nutrients. 2016;8(12).

61. Cannell JJ, Vieth R, Umhau JC, Holick MF, Grant WB, Madronich S, et al. Epidemic influenza and vitamin D. Epidemiology and infection. 2006;134(6):1129-40. 62. Pfleiderer M, Lower J, Kurth R. Cold-attenuated live influenza vaccines, a risk-benefit assessment. Vaccine. 2001;20(5-6):886-94.

63. Lundqvist A, Sandstrom H, Stenlund H, Johansson I, Hultdin J. Vitamin D Status during Pregnancy: A Longitudinal Study in Swedish Women from Early Pregnancy to Seven Months Postpartum. PloS one. 2016;11(3):e0150385.

64. Petersen SB, Olsen SF, Molgaard C, Granstrom C, Cohen A, Vestergaard P, et al. Maternal vitamin D status and offspring bone fractures: prospective study over two decades in Aarhus City, Denmark. PloS one. 2014;9(12):e114334.

65. $\quad$ Eggemoen AR, Falk RS, Knutsen KV, Lagerlov P, Sletner L, Birkeland KI, et al. Vitamin D deficiency and supplementation in pregnancy in a multiethnic populationbased cohort. BMC pregnancy and childbirth. 2016;16:7.

66. Barebring L, Schoenmakers I, Glantz A, Hulthen L, Jagner A, Ellis J, et al. Vitamin D Status during Pregnancy in a Multi-Ethnic Population-Representative Swedish Cohort. Nutrients. 2016;8(10).

67. Mantel N, Haenszel W. Statistical aspects of the analysis of data from retrospective studies of disease. Journal of the National Cancer Institute. 1959;22(4):719-48.

68. Wang JW, Hogan PG, Hunstad DA, Fritz SA. Vitamin D sufficiency and Staphylococcus aureus infection in children. The Pediatric infectious disease journal. 2015;34(5):544-5. 
69.

Matheson EM, Mainous AG, 3rd, Hueston WJ, Diaz VA, Everett CJ. Vitamin D and methicillin-resistant Staphylococcus aureus nasal carriage. Scandinavian journal of infectious diseases. 2010;42(6-7):455-60.

70. Magann EF, Doherty DA, Sandlin AT, Chauhan SP, Morrison JC. The effects of an increasing gradient of maternal obesity on pregnancy outcomes. The Australian \& New Zealand journal of obstetrics \& gynaecology. 2013;53(3):250-7.

71. Wloch C, Wilson J, Lamagni T, Harrington P, Charlett A, Sheridan E. Risk factors for surgical site infection following caesarean section in England: results from a multicentre cohort study. BJOG : an international journal of obstetrics and gynaecology. 2012;119(11):1324-33.

72. Ely JW, Rijhsinghani A, Bowdler NC, Dawson JD. The association between manual removal of the placenta and postpartum endometritis following vaginal delivery. Obstetrics and gynecology. 1995;86(6):1002-6.

73. Yamasato K, Kimata C, Burlingame JM. Associations Between Maternal Obesity and Race, with Obstetric Anal Sphincter Injury: A Retrospective Cohort Study. Hawai'i journal of medicine \& public health : a journal of Asia Pacific Medicine \& Public Health. 2019;78(1):8-12.

74. Blomberg M. Maternal body mass index and risk of obstetric anal sphincter injury. BioMed research international. 2014;2014:395803.

75. Turcksin R, Bel S, Galjaard S, Devlieger R. Maternal obesity and breastfeeding intention, initiation, intensity and duration: a systematic review. Maternal \& child nutrition. 2014;10(2):166-83.

76. Ramji N, Challa S, Murphy PA, Quinlan J, Crane JMG. A comparison of breastfeeding rates by obesity class. The journal of maternal-fetal \& neonatal medicine : the official journal of the European Association of Perinatal Medicine, the Federation of Asia and Oceania Perinatal Societies, the International Society of Perinatal Obstet. 2018;31(22):3021-6.

77. Messerlian C, Basso O. Cohort studies in the context of obstetric and gynecologic research: a methodologic overview. Acta obstetricia et gynecologica Scandinavica. 2018;97(4):371-9.

78. Seijo M, Minckas N, Cormick G, Comande D, Ciapponi A, BelizAn JM. Comparison of self-reported and directly measured weight and height among women of reproductive age: a systematic review and meta-analysis. Acta obstetricia et gynecologica Scandinavica. 2018;97(4):429-39.

79. Natamba BK, Sanchez SE, Gelaye B, Williams MA. Concordance between self-reported pre-pregnancy body mass index (BMI) and BMI measured at the first prenatal study contact. BMC pregnancy and childbirth. 2016;16(1):187.

80. Mattsson K, Kallen K, Rignell-Hydbom A, Lindh CH, Jonsson BA, Gustafsson $\mathrm{P}$, et al. Cotinine Validation of Self-Reported Smoking During Pregnancy in the Swedish Medical Birth Register. Nicotine \& tobacco research : official journal of the Society for Research on Nicotine and Tobacco. 2016;18(1):79-83.

81. B K, K K. The Swedish Medical Birth Register: a summary of content and quality.: National Board of Health and Welfare; 2003 [2003-112-3:[Available from: https://www.socialstyrelsen.se/Lists/Artikelkatalog/Attachments/10655/2003-1123_20031123.pdf. 


\section{APPENDIX}

\section{LANDSTINGET \\ Tjänsteställe/handläggare}

Kvinnokliniken, Länssjukhuset Ryhov

Daniel Axelsson
Datum

2009-06-08

Namn:

Personnummer:

Förlossningsdatum:

Kryssa i det påstående som stämmer:

Har du haft någon infektion efter din förlossning (inom 2 månader)

Ja Nej

Om du svarat Ja vänligen fortsätt med följande frågor

Jag har haft sårinfektion (i operationssår eller bristningar i underlivet)

Ja Nej

Jag har haft urinvägsinfektion

Jag har haft livmoderinflammation

Jag har haft infektion i brösten

Har du fått antibiotikabehandling för någon/några av ovanstående infektioner?

För vilken infektion/vilka infektioner har du fătt antibiotika?
$\square$ Sårinfektion
$\square$ Urinvägsinfektion
$\square$ Livmoderinflammation
Infektion i brösten

Jag har haft en annan infektion (ange vilken) 


\section{Papers}

The papers associated with this thesis have been removed for copyright reasons. For more details about these see:

http://urn.kb.se/resolve?urn=urn:nbn:se:liu:diva-156877 
